\title{
BONE LESIONS IN COMPRESSED AIR WORKERS
}

\author{
With Special Reference to Men who Worked on the Clyde Tunnels 1958 to 1963
}

REPORT OF DECOMPRESSION SICKNESS PANEL, MEDICAL RESEARCH COUNCIL*

\author{
Prepared by \\ R. I. MCCallum and D. N. Walder \\ with the assistance of
}

R. Barnes, M. E. Catto, J. K. Davidson, D. I. Fryer, F. C. Golding and W. D. M. Paton

From the Medical Research Council Decompression Sickness Registry, University of Newcastle upon Tyne, England

Chronic disease of bone is one of the hazards of working in compressed air. The lesion is variously described as caisson disease, avascular necrosis or aseptic necrosis of bone. In this paper we use the term " aseptic necrosis of bone." Although the first report of bone necrosis in a compressed air worker has been attributed to Twynam (1888), his description was rather that of osteomyelitis; the infection which was clearly present in his patient is, by definition, absent in aseptic necrosis.

The radiographic appearances of aseptic necrosis of bone caused by decompression were first described by Bornstein and Plate (1911) and independently by Bassoe (1913).

Bone necrosis in compressed air workers has often been reported in single cases or in small series of cases but, in general, these reports lack sufficient detail from which to identify the causative factors. In British literature there are reports by Walker (1940), Swain (1942), McCallum, Stanger, Walder and Paton (1954), Thomson and Young (1958), and Bucky (1959). In American literature there are reports by Coley and Moore (1940), Rendich and Harrington (1940), and Poppel and Robinson (1956). In European literature there are reports 1) from France by Charles, Cavigneaux, Fuchs and Tara (1948), Bourret, Fraisse and Fraisse (1948), Fischgold, Coville and Doassans (1948), Raymond (1948), Bétoulières and Boulouys (1952), Guitard (1953), Ravault, Merer, Roche and Rayneau (1953), Roche and Rayneau (1953), Bureau, Horeau and Lemeillet (1955), Tara (1956), Fournier and Jullien (1959), Raymond (1960), and Nicolet, Merer and Jaffres (1961);2) from Italy by Balestra and Molfino (1949), Angei and Cossu (1954), Mauro (1959), Mauro and Saggese (1959), Francia and Quaglia (1959), and Molfino (1961); 3) from Germany by Rettig (1951), Schröder (1956), Liess (1956), and Fründ (1956); and 4) from Hungary by Déak and Rózsahegyi (1956). Other reports include those by Horvath (1958), Meesters (1958) and Kaczurba (1962) from Europe; and by Rose (1962) from New Zealand. Reference should be made to Rózsahegyi (1956) for a summary of cases of aseptic necrosis of bone in compressed air workers published in the literature before 1955 .

The typical bone lesions described in these papers were often bilateral and were situated in the proximal end of the humerus and in the proximal or distal ends of the femur. Symptoms were present only when an articular surface had become involved, and sometimes this did not occur until a considerable time after the last exposure to compressed air. The articular surface of the humeral head was affected more often than the articular surface of the femoral head,

\section{* Medical Research Council Decompression Sickness Panel 1965}

Mr D. N. Walder (Chairman)

Mr H. V. Hempleman (Secretary) Professor Roland Barnes

Dr A. H. Baynes

Dr M. J. Catton

Dr P. J. Chapman

VOl. 48 B, NO. 2, MAY 1966
Dr J. K. Davidson Wing Commander D. I. Fryer

Dr F. Campbell Golding

Dr P. D. Griffiths

Dr R. I. McCallum
Dr B. McStay Professor W. D. M. Paton

Dr E. C. Poulton

Dr W. R. Tidy

Dr R. F. Tuckett 
and the articular surfaces of the knee joints were never involved. Not all the men with radiographic evidence of bone necrosis were said to have experienced symptoms of acute decompression sickness.

Diagnosis-Several papers demonstrate the similarity of the radiographic changes of bone necrosis after work in compressed air to those from other causes. Taylor (1943) reported aseptic necrosis of bone in a series of fifty patients. Twelve had been exposed at some time to high atmospheric pressure, but thirty-eight had never been in compressed air although they were said to have the "same characteristic lesions" as the others. Kahlstrom, Burton and Phemister (1939) and Bucky (1959) also described bone necrosis in patients who had never been in compressed air.

The difficulty of differentiating between secondary osteoarthritis following aseptic necrosis of the head of the femur and osteoarthritis from other causes is discussed by Jullien, Leandri and Desanti (1954), Mosinger and Jullien (1961) and Gaultier, Fournier, Gervais and Ract (1962).

The value of macroradiography (Reboul, Delos, Delorme, Groc, Bordron and Carraze 1955) and tomography (Roche, Devic, Genevois and Marin 1956; Suntych and Suntychova 1961 ) in the detection of early lesions of bone necrosis has been clearly shown.

Pathology-Compared with the extensive literature on the radiographic appearances of the bones of compressed air workers, little has been written about the pathological changes of the affected areas. The pathology of this condition was first described by Kahlstrom. Burton and Phemister (1939). They observed areas of bone necrosis in which the lacunae of the trabeculae were devoid of cells and were surrounded by walls of patchily calcified and partly ossified dense connective tissue. The cases studied were all of long standing and had marked secondary changes of osteoarthritis. Similar descriptions of pathological findings have also been given by Swain (1942) and de Sèze, Durieu, Brux, Guéguen and Welfing (1951).

Single exposures-The possibility that a single exposure to compressed air may produce bone necrosis has been raised from time to time. Barbara and Isola (1939) described the development of bone necrosis in the head of the femur, and in the heads of both humeri, in a man aged thirty-two after one exposure to four atmospheres absolute pressure for four hours. Guillain and Grossiord (1943) recorded a case of bone necrosis after a single exposure of four hours. Taylor (1944) mentioned that in one of his cases there had been only one exposure to compressed air. Perhaps most convincing is the experience of James (1945), who, twelve years after the incident, found aseptic necrosis of bone in three of the five survivors from the submarine H.M.S. Poseidon, which sank in 1931 in 120 feet of water (4.75 atmospheres absolute). Lesions were present in the neck of the left humerus of one man, and in both femoral and humeral heads of a second man; there were lesions in the shaft of the left femur and head of the left humerus in a third man. The changes apparently followed a single exposure to compressed air of approximately three hours.

Prevalence of bone lesions in compressed air workers-From the evidence published so far it is not possible to assess accurately the prevalence of aseptic necrosis of bone in compressed air workers. One of the earliest reports of radiographic findings in a group of compressed air workers appears to be that of Bell, Edson and Hornick (1942). These authors examined thirty-eight men and found aseptic necrosis of bone in 75 per cent. As these men were a selected group of workers who were claiming compensation, it is difficult to assess the significance of the findings.

Nicolas (1949) stated that one in twenty (5 per cent) of compressed air workers showed radiographic evidence of bone necrosis. Cavigneaux, Charles, Fuchs and Tara (1949) found that the bone radiographs of forty-eight out of 125 caisson workers ( 38 per cent) were abnormal. Lewis and Paton (1957) failed to find any bone lesions in twenty caisson workers. Mungo and Sessa (1958) examined the radiographs of the hips, shoulders and knee joints of forty-seven compressed air workers and reported abnormalities in fourteen (34 per cent). From the very 
well reproduced radiographs in this paper it can be seen that many of the abnormal findings resembled bone islands and some of the changes appeared to be indefinite.

In an investigation by the Medical Research Council's Decompression Sickness Panel (Golding, Griffiths, Hempleman, Paton and Walder 1960) during the construction of the Dartford tunnel, when radiographs were taken of shoulders, hips and knee joints, ten of eighty-three (12 per cent) experienced compressed air workers with a history of one or more attacks of bends had demonstrable bone changes, as did three of twenty without a history of treatment for bends. It was pointed out that the extent to which bone changes occur in men without symptoms has scarcely been explored.

Rózsahegyi and Fried (1963) found aseptic necrosis of bone in 22 per cent of sixty-six compressed air workers employed on the construction of the Budapest underground. Many of these men were symptom-free and no close relationship was found between decompression sickness and bone changes, but the authors stated that the more attacks of bends a man suffered, the more likely he was to develop bone necrosis.

Aseptic necrosis of bone in divers-Aseptic necrosis of bone appears to be much less frequent in divers than in compressed air workers. Ronald (1953) described one case in Britain, and Herget (1948) in Germany found aseptic necrosis in thirteen of forty-seven divers (28 per cent). The lesions were said to have the same features as those found in compressed air workers and to occur more frequently in the head of the humerus than in other bones. Other cases of bone necrosis in divers were reported, one by Sartor (1947), two by Dale (1952), three by Slørdahl (1953) and three by Pirastu and Perra (1960). More recently Kirjakov (1964) has also reported bone changes in divers.

Aseptic necrosis of bone in aviators-Aseptic necrosis of bone in those exposed to subatmospheric decompression is the subject of conflicting reports. Ratnoff (1943) found no radiographic evidence of bone necrosis in the hip joints of twenty-one men up to two and a half years after they had been exposed intermittently to simulated altitudes of about 35,000 feet in low pressure chambers, and Allan (1943) found no changes in three other men exposed to low pressures. Coburn (1956) claimed to have found evidence of bone necrosis in 17 per cent of forty low pressure chamber operators in the United States Navy. Berry and Hekhuis (1960), in a radiographic survey of 579 low pressure chamber workers in the United States Air Force, were unable to find evidence of bone necrosis in the shoulders, hips or knee joints, although approximately half these men had experienced acute decompression sickness. The length of exposure and the time interval between the first exposure and radiographic examination were not stated.

\section{THE CLYDE TUNNELS}

Two parallel tunnels have been constructed under the Clyde between Linthouse and Whiteinch where the river is $\mathbf{4 0 0}$ feet wide; they lie about twenty-one feet below the river bed in sandstone and shale overlaid by glacial and alluvial deposits. Work in compressed air began in February 1958 and continued with breaks of a few weeks in free air until January 1963 (Fig. 1). Early in the contract, when the air pressure was being increased from 10 pounds per square inch gauge to 32.5 pounds per square inch gauge over a period of three months, the incidence of decompression sickness rose appreciably, so that it was decided to lengthen by an average of seven minutes the statutory decompression times for exposures of four hours or more for the remainder of the contract (Haxton and Whyte 1965).

Radiographic investigation-This paper reports an investigation of 241 men who had worked at pressures up to 35 pounds per square inch gauge on the construction of two tunnels under the River Clyde at Glasgow. A further six men also employed at that time refused examination. Radiographs were taken of major joints and the adjacent bone shafts: 1) to determine the prevalence of bone lesions; 2 ) to provide information about the time of onset of radiological changes; and 3) to attempt to relate these changes to working pressure and length of exposure.

VOL. 48 B, NO. 2, MAY 1966 
The investigation was carried out in November 1962 when, with the help of the contractors, arrangements were made for the men to attend a nearby hospital.

Antero-posterior radiographs of the hips and shoulders and antero-posterior and lateral views of the knee joints were taken. As much as possible of the femur and tibia was included to detect shaft lesions. It had been found during the Dartford tunnel investigation (Golding and colleagues 1960) that lateral views of the lower end of the femur were essential to detect early lesions in this region because the antero-posterior film did not always show them clearly.

The contractors' agent and a member of the Medical Research Council Decompression Sickness Panel explained to the men the purpose of the investigation. The men were also given a leaflet pointing out that the survey was part of medical research into the diseases of tunnel workers. If a significant radiological abnormality was found the patient was informed at interview and arrangements made for him to obtain further medical advice if he so wished. If no significant lesion was found the man was informed by letter.

GLYOE TUNNEL AIR PRESSURE

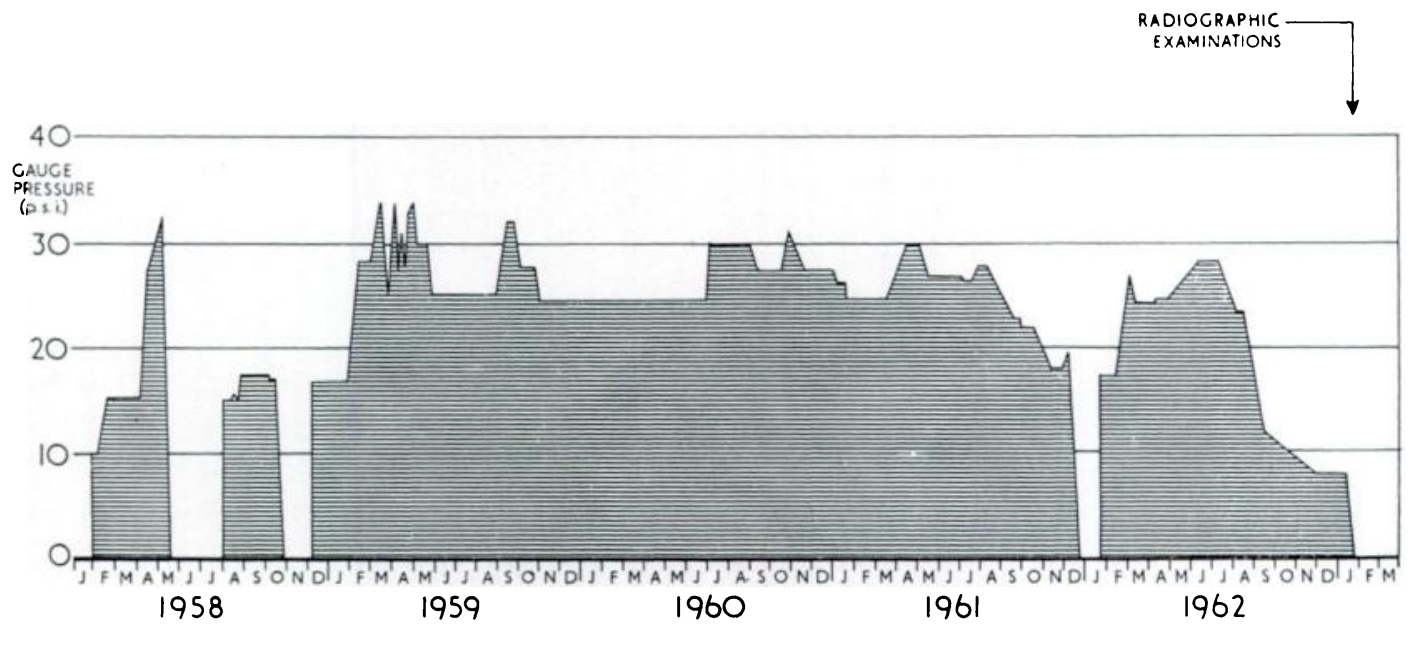

Fig. 1

Simplified diagram of the air pressures used during construction of the Clyde tunnels. Because work was proceeding simultaneously on more than one tunnel face, all the men were not necessarily working at the same pressure. Only the highest pressure in use at any one time is shown.

All the radiographs were examined twice by each of two radiologists (F. C. G. and J. K. D.) working separately, and once by both radiologists working together. Although the radiologists knew that all the radiographs were of men who had worked in compressed air, they did not know which of the men had been treated for decompression sickness. The radiographs were classified as showing definite, doubtful, or no evidence of aseptic necrosis. Lesions were described according to site as "juxta-articular" when close to an articular surface, or " head, neck or shaft" (Table I).

Results-Evidence of bone necrosis was found in forty-seven men (19 per cent) and doubtful evidence in a further nineteen. This latter group has been excluded from the following analysis. Some men with lesions also had doubtful lesions (Table I).

There were altogether thirty-three juxta-articular lesions, of which twelve involved femora and twenty-one involved humeri. Both femora were affected in three men, and one femur was affected in six men. Both humeri were affected in six men, and one humerus was affected in nine men. Head, neck or shaft lesions were found in thirty-four men and were seen more frequently in lower limbs (thirty-five lesions) than in upper limbs (twenty-three lesions). It is remarkable how infrequently the tibia was involved (seven lesions), but only part of the upper 
TABLE I

Men With at Least One Radiographic Bone Lesion

J Juxta-articular lesions. S : Head, neck or shaft lesions. Doubtful lesions are preceded by a question mark

\begin{tabular}{|c|c|c|c|c|c|c|c|c|c|}
\hline \multirow{2}{*}{$\begin{array}{c}\text { Case } \\
\text { number }\end{array}$} & \multicolumn{2}{|c|}{ Humerus } & \multicolumn{2}{|c|}{ Femur (upper) } & \multicolumn{2}{|c|}{ Femur (lower) } & \multicolumn{2}{|c|}{ Tibia (upper) } & \multirow{2}{*}{$\begin{array}{l}\text { History of work in } \\
\text { compressed air } \\
\text { before Clyde contract }\end{array}$} \\
\hline & Right & Left & Right & Left & Right & Left & Right & Left & \\
\hline 1 & $\mathbf{J}$ & $\mathbf{J}$ & - & - & - & - & - & - & Yes \\
\hline 2 & $\mathbf{J}$ & $\mathbf{J}$ & $\mathbf{S}$ & - & - & - & - & - & Yes \\
\hline 3 & $\mathbf{J}$ & $\mathbf{J}$ & - & - & - & - & - & - & No \\
\hline 4 & ?S & - & $\mathbf{J}$ & $\mathbf{J}$ & $\mathbf{S}$ & - & - & - & Yes \\
\hline 5 & $\mathbf{S}$ & $\mathbf{S}$ & - & $\mathbf{S}$ & - & - & - & - & No \\
\hline 6 & $\mathbf{S}$ & - & - & - & - & - & - & - & No \\
\hline 7 & - & - & $\mathbf{S}$ & - & - & - & - & - & No \\
\hline 8 & - & $\mathbf{J}$ & - & ?S & - & - & - & - & No \\
\hline 9 & - & - & $\mathbf{S}$ & - & - & - & - & - & No \\
\hline 10 & - & ?J & - & ?J & $\mathbf{S}$ & $\mathbf{S}$ & $\mathbf{S}$ & - & No \\
\hline 11 & - & - & - & - & $\mathbf{S}$ & ?S & - & - & Yes \\
\hline 12 & $\mathbf{J}$ & - & - & ?J & - & - & - & - & No \\
\hline 13 & - & ?S & - & - & - & - & $\mathbf{S}$ & - & Yes \\
\hline 14 & - & $\mathbf{S}$ & - & - & - & $\mathbf{S}$ & - & - & No \\
\hline 15 & - & $\mathbf{J}$ & - & - & - & - & - & - & No \\
\hline 16 & $\mathbf{S}$ & $\mathbf{S}$ & $\mathbf{J}$ & $\mathbf{J}$ & - & $\mathbf{S}$ & - & - & No \\
\hline 17 & $\mathbf{S}$ & $\mathbf{S}$ & - & - & - & - & - & - & No \\
\hline 18 & - & - & - & - & $\mathbf{S}$ & - & - & - & No \\
\hline 19 & $\mathbf{J}$ & $\mathbf{J}$ & - & - & - & - & - & - & No \\
\hline 20 & $\mathbf{S}$ & $\mathbf{S}$ & SJ & $\mathbf{J}$ & - & - & - & - & Yes \\
\hline 21 & - & - & - & - & - & $\mathbf{S}$ & - & - & No \\
\hline 22 & $\mathbf{J}$ & - & - & - & - & - & - & - & No \\
\hline 23 & - & SJ & - & - & - & - & - & - & No \\
\hline 24 & - & - & - & - & $\mathbf{S}$ & $\mathbf{S}$ & - & - & Yes \\
\hline 25 & $\mathbf{J}$ & $\mathbf{J}$ & - & - & - & - & - & - & No \\
\hline 26 & $\mathbf{J}$ & $\mathbf{J}$ & - & - & - & - & - & - & No \\
\hline 27 & - & $\mathbf{S}$ & - & - & - & ?S & - & - & No \\
\hline 28 & - & $\mathbf{J}$ & ?J & - & - & - & - & - & No \\
\hline 29 & - & - & $\mathbf{J}$ & - & $\mathbf{S}$ & $\mathbf{S}$ & $\mathbf{S}$ & $\mathbf{S}$ & No \\
\hline 30 & $\mathbf{S}$ & $\mathbf{S}$ & - & - & - & - & - & - & No \\
\hline 31 & ?S & $\mathbf{S}$ & ?S & - & ?S & - & - & - & No \\
\hline 32 & $\mathbf{J}$ & - & - & - & - & - & - & - & No \\
\hline 33 & - & $\mathbf{S}$ & - & - & $\mathbf{S}$ & $\mathbf{S}$ & - & - & No \\
\hline 34 & - & - & $\mathbf{S}$ & $\mathbf{S}$ & ?S & - & - & - & No \\
\hline 35 & $\mathbf{S}$ & - & - & - & - & - & - & - & Yes \\
\hline 36 & - & $\mathbf{J}$ & - & $\mathbf{J}$ & - & - & - & - & No \\
\hline 37 & - & - & $\mathbf{J}$ & - & $\mathbf{S}$ & - & - & - & Yes \\
\hline 38 & $\mathbf{S}$ & - & - & - & - & - & - & - & No \\
\hline 39 & - & SJ & - & - & - & - & - & - & No \\
\hline 40 & $? \mathrm{~S}$ & $\mathbf{S}$ & - & $\mathbf{J}$ & - & - & - & - & No \\
\hline 41 & - & ?S & - & ?S & $\mathbf{S}$ & $\mathbf{S}$ & - & - & No \\
\hline 42 & - & - & - & $\mathbf{J}$ & ?S & - & - & - & No \\
\hline 43 & $\mathbf{S}$ & - & - & - & - & $\mathbf{S}$ & - & - & No \\
\hline 44 & $\mathbf{S}$ & $\mathbf{S}$ & - & - & - & - & - & - & No \\
\hline 45 & - & - & - & - & $\mathbf{S}$ & $\mathbf{S}$ & $\mathbf{S}$ & $\mathbf{S}$ & No \\
\hline 46 & - & - & - & - & - & - & $\mathbf{S}$ & - & No \\
\hline 47 & - & - & - & SJ & - & - & 一 & - & No \\
\hline
\end{tabular}

VOL. 48 B, NO. 2, MAY 1966 
end of the bone was visible in the radiographs. No lesion was seen in those parts of the pelvis, scapula, clavicle and ribs included on the radiographs.

Of the forty-seven men with one or more bone lesions, thirty-eight claimed that the Clyde contract was their first experience of work in compressed air; so in these men any bone changes characteristic of aseptic necrosis may reasonably be ascribed to working on this particular contract.

Computer analysis-One of the most important problems requiring a solution is the precise nature of the relationship between the occurrence of a bone lesion and exposure to compressed air. For each man information was available about the number of decompressions to which he had been exposed during the Clyde contract, the air pressures at which he had worked and his history of treatment for simple bends (Type I decompression sickness) and the more serious manifestations (Type II decompression sickness-Golding and colleagues 1960), and whether or not he had ever worked in compressed air before this contract.

All the above information, together with the results of the radiological examination of the bones, was abstracted on to record sheets from which it was transferred to punched tape for analysis by a Pegasus computer in the University of Newcastle upon Tyne.

MEN WHO HAD NEVER BEEN EXPOSED TO COMPRESSED AIR BEFORE THE CLYDE CONTRACT

Bone lesions and decompressions-The 223 men who first experienced work in compressed air in this contract were divided into those with and those without a bone lesion and classified according to the number of decompressions experienced (Table IIA). It can be seen that as a group the men with bone lesions had experienced significantly more decompressions than those without a bone lesion $(p<0.01)$. Further analysis of these figures shows that as the number of decompressions increases there is a corresponding rise in the proportion of men with bone lesions. This increases from 8.6 per cent in men who experienced fewer than 300 decompressions to 30.4 per cent in men who experienced more than 900 decompressions (Table IIB).

Bone lesions and maximum pressure experienced-If the men are grouped according to the maximum pressure at which they worked in this contract it can be seen that the proportion of men with bone lesions increases significantly among those who were exposed at some time to pressures over 30 pounds per square inch gauge (Table III).

Bone lesions and decompression sickness. Type I decompression sickness (bends)-In the group of men with one or more bone lesions 45 per cent were known to have been treated for bends, whereas in the group without bone lesions only 14 per cent were known to have been so treated, a difference which is statistically significant (Table IV). We found no statistically significant relationship between the sites of the bone lesions and the sites of bends.

Type II decompression sickness-Only nine cases of Type II decompression sickness occurred in those without previous compressed air experience and there was no tendency for this type of decompression sickness to be associated with the development of bone lesions (Table V).

MEN WHO HAD BEEN EXPOSED TO COMPRESSED AIR BEFORE THE CLYDE CONTRACT

Bone lesions and decompressions-In the eighteen men with a history of exposure to compressed air in other contracts no association between bone lesions and the number of decompressions during the Clyde contract was evident (Table VI).

Bone lesions and maximum pressure experienced-The presence or absence of a bone lesion was not related statistically to the maximum pressure at which a man had worked during this contract (Table VII).

Bone lesions and decompression sickness-It was not possible to show any statistically significant association between the number of men with bone lesions and the number with a previous history of decompression sickness of either Type I (bends) or Type II. However, no information 
TABLE II

Bone Lesions and Decompressions in Those Without Previous COMPRESSED AIR EXPERIENCE

A. Men with and without bone lesions (total 223)

\begin{tabular}{|c|c|c|}
\hline $\begin{array}{l}\text { Number of } \\
\text { decompressions }\end{array}$ & $\begin{array}{l}\text { Number of men } \\
\text { without bone lesions }\end{array}$ & $\begin{array}{l}\text { Number of men } \\
\text { with bone lesions }\end{array}$ \\
\hline $\begin{array}{c}1-74 \\
75-149 \\
150-224 \\
225-299 \\
300-374 \\
375-449 \\
450-524 \\
525-599 \\
600-674 \\
675-749 \\
750-824 \\
825-899 \\
900-974 \\
975-1,049 \\
1,050-1,124 \\
1,125-1,199 \\
1,200-1,274 \\
1,275-1,349 \\
1,350-1,424 \\
1,425-1,499 \\
1,500-1,574 \\
1,575-1,649 \\
1,650-1,724\end{array}$ & $\begin{array}{r}10 \\
12 \\
15 \\
16 \\
10 \\
13 \\
12 \\
15 \\
8 \\
9 \\
7 \\
10 \\
3 \\
7 \\
5 \\
5 \\
2 \\
9 \\
3 \\
3 \\
1 \\
3 \\
7\end{array}$ & $\begin{array}{l}1 \\
1 \\
2 \\
1 \\
0 \\
3 \\
0 \\
1 \\
2 \\
2 \\
1 \\
3 \\
5 \\
2 \\
2 \\
1 \\
1 \\
3 \\
2 \\
1 \\
2 \\
1 \\
1\end{array}$ \\
\hline Total number of men & 185 & 38 \\
\hline $\begin{array}{l}\text { Average number of } \\
\text { decompressions }\end{array}$ & 646 (S.E. $\div 34$ ) & 908 (S.E. : : 72) \\
\hline Difference . & \multicolumn{2}{|c|}{$262($ S.E. \pm 81$)(p<0.01)$} \\
\hline
\end{tabular}

B. Men with bone lesions

\begin{tabular}{|c|c|c|c|}
\hline $\begin{array}{c}\text { Number of } \\
\text { decompressions }\end{array}$ & Total men & $\begin{array}{l}\text { Men with } \\
\text { bone lesions }\end{array}$ & $\begin{array}{l}\text { Percentage with } \\
\text { bone lesions }\end{array}$ \\
\hline $\begin{array}{c}<300 \\
300-599 \\
600-899 \\
900 \text { and over }\end{array}$ & $\begin{array}{l}58 \\
54 \\
42 \\
69\end{array}$ & $\begin{array}{r}5 \\
4 \\
8 \\
21\end{array}$ & $\begin{array}{l}8 \cdot 6 \\
7 \cdot 4 \\
19 \\
30 \cdot 4\end{array}$ \\
\hline Total . & 223 & 38 & 17 \\
\hline
\end{tabular}

TABLE III

Bone Lesions and Maximum Pressure Experienced in Those Without Previous Exposure to Compressed Air

\begin{tabular}{|c|c|c|c|c|c|}
\hline & \multicolumn{4}{|c|}{ Maximum gauge pressure (pounds per square inch) } & \multirow{2}{*}{ Total } \\
\hline & 18 & 25 & 30 & 34 & \\
\hline Men with bone lesion & $1(6$ per cent $)$ & $3(10$ per cent $)$ & 10 (11 per cent $)$ & 24 ( 29 per cent $)$ & 38 ( 17 per cent $)$ \\
\hline Men without bone lesion & 17 & 27 & 83 & 58 & 185 \\
\hline Total. & 18 & $\ldots \ldots$ & 93 & 82 & 223 \\
\hline \multicolumn{6}{|c|}{ There is a significant association between lesion and pressure $\left(x^{2}=14\right.$, d.f. $\left.=3, p<0.01\right)$} \\
\hline
\end{tabular}

VOL. 48 B. No. 2, MAY 1966 
TABLE IV

Bone Lesions and Type I Decompression Sickness (Bends) in Those Without Previous Compressed Air Experience

\begin{tabular}{|c|c|c|}
\hline $\begin{array}{l}\text { Number of } \\
\text { recompressions for } \\
\text { Type I decompression } \\
\text { sickness (bends) }\end{array}$ & $\begin{array}{l}\text { Men with } \\
\text { bone lesions }\end{array}$ & $\begin{array}{l}\text { Men without } \\
\text { bone lesions }\end{array}$ \\
\hline 1 & 8 & 11 \\
\hline 2 & 7 & 7 \\
\hline 3 & 19 - & 2 \\
\hline 4 & ${ }_{1}{ }^{45}$ per cent & $2{ }^{14}$ per cent \\
\hline 5 & 0 & 1 \\
\hline 8 & 0 & 2 \\
\hline 0 & $21 \quad(55$ per cent $)$ & 160 (86 per cent) \\
\hline Total & 38 & 185 \\
\hline \multicolumn{3}{|c|}{$\begin{array}{l}\text { Significantly more of the men with lesions have at least one bend } \\
\qquad x^{2}:=18 \cdot 1 \text {, d.f. }=1, p<0.001\end{array}$} \\
\hline
\end{tabular}

TABLE V

Bone Lesions and Type II Decompression Sickness in Those Without Previous Compressed Air EXPerience

\begin{tabular}{|c|c|c|}
\hline $\begin{array}{c}\text { Number of } \\
\text { recompressions for } \\
\text { Type II decompression } \\
\text { sickness }\end{array}$ & $\begin{array}{c}\text { Men with } \\
\text { bone lesions }\end{array}$ & $\begin{array}{c}\text { Men without } \\
\text { bone lesions }\end{array}$ \\
\hline 1 & 2 & 5 \\
2 & 0 & 178 \\
\hline 0 & 36 & 185 \\
\hline Total & 38 & \\
\hline
\end{tabular}

TABLE VI

Bone Lesions and Decompressions in Those With Previous Compressed Air Experience

\begin{tabular}{|c|c|c|}
\hline & Without bone lesions & With bone lesions \\
\hline Number of men & 9 & 9 \\
\hline Average number of decompressions . & 1,090 & 1,156 \\
\hline Range of number of decompressions & $498-1,652$ & $662-1,536$ \\
\hline $\begin{array}{l}\text { Difference between average number } \\
\text { of decompressions. }\end{array}$ & \multicolumn{2}{|c|}{66 (S.E. 173) (not significant) } \\
\hline
\end{tabular}


BONE LESIONS IN COMPRESSED AIR WORKERS

TABLE VII

Bone Lesions and Maximum Pressure Experienced in Those With Previous Exposure to Compressed Air

\begin{tabular}{|c|c|c|c|}
\hline & \multicolumn{2}{|c|}{$\begin{array}{l}\text { Maximum gauge pressure } \\
\text { (pounds per square inch) }\end{array}$} & \multirow[t]{2}{*}{ Total } \\
\hline & 30 & 34 & \\
\hline Men with bone lesion & 3 & 6 & 9 \\
\hline Men without bone lesion & 3 & 6 & 9 \\
\hline Total & 6 & 12 & 18 \\
\hline
\end{tabular}

TABLE VIII

Bone Lesions and Type I Decompression Sickness (Bends) in Those With Previous Compressed Air Experience

\begin{tabular}{|ccc|}
\hline $\begin{array}{c}\text { Number of } \\
\text { recompressions for } \\
\text { Type I decompression } \\
\text { sickness (bends) }\end{array}$ & $\begin{array}{c}\text { Men with } \\
\text { bone lesions }\end{array}$ & $\begin{array}{c}\text { Men without } \\
\text { bone lesions }\end{array}$ \\
\hline 1 & 4 & 3 \\
2 & 0 & 2 \\
7 & 1 & 0 \\
0 & 4 & 4 \\
\hline Total & 9 & 9 \\
\hline
\end{tabular}

TABLE IX

Bone Lesions ANd Type II Decompression Sickness in Those With Previous Compressed Air Experience

\begin{tabular}{|c|c|c|}
\hline $\begin{array}{c}\text { Number of } \\
\text { recompressions for } \\
\text { Type II decompression } \\
\text { sickness }\end{array}$ & $\begin{array}{c}\text { Men with } \\
\text { bone lesions }\end{array}$ & $\begin{array}{c}\text { Men without } \\
\text { bone lesions }\end{array}$ \\
\hline 1 & 4 & 2 \\
2 & 2 & 1 \\
0 & 3 & 6 \\
\hline Total & 9 & 9 \\
\hline
\end{tabular}

TABLE X

Bone Lesions in Men With and Without Previous Compressed Air Experience

\begin{tabular}{|l|c|c|}
\hline & $\begin{array}{c}\text { Men with previous } \\
\text { compressed air experience }\end{array}$ & $\begin{array}{c}\text { Men without previous } \\
\text { compressed air experience }\end{array}$ \\
\hline $\begin{array}{c}\text { Total number of men } \\
\text { Number with bone lesions }\end{array}$ & 18 & 223 \\
& $9(50$ per cent $)$ & $38(17$ per cent $)$ \\
\hline There is a significant association $x^{2-}=9 \cdot 5$, d.f. $-1, p<0.01$
\end{tabular}

vol. 48 B. NO. 2, MAY 1966 
TABLE XI

Recompressions for TyPe I Decompression Sickness in Men With and Wrthout Previous Compressed Air Experience

\begin{tabular}{|c|c|c|}
\hline $\begin{array}{l}\text { Number of } \\
\text { recompressions for } \\
\text { Type I decompression } \\
\text { sickness (bends) }\end{array}$ & $\begin{array}{l}\text { Men with previous } \\
\text { compressed air } \\
\text { experience }\end{array}$ & $\begin{array}{l}\text { Men without previous } \\
\text { compressed air } \\
\text { experience }\end{array}$ \\
\hline 1 & 7) & 19 \\
\hline 2 & 2 & 14 \\
\hline 3 & 0 & 3 \\
\hline $\begin{array}{l}4 \\
5\end{array}$ & 0 (56 per cent & $\begin{array}{ll}3 & \\
1 & 19 \text { per cent }\end{array}$ \\
\hline 6 & 0 & 0 \\
\hline 7 & 1 & 0 \\
\hline 8 & 0 & 2 \\
\hline 0 & 8 (44 per cent) & 181 (81 per cent $)$ \\
\hline Total & $\begin{array}{l}18 \\
11 \cdot 2, \text { d.f. } \quad 1, \mathrm{p}<0\end{array}$ & 223 \\
\hline
\end{tabular}

TABLE XII

ReCOMPRESSIONS for TyPe II DeCOMPRESSION SiCKNESS IN MEN With and Without Prfilous Compressed Air Experience

\begin{tabular}{|c|c|c|}
\hline $\begin{array}{c}\text { Number of } \\
\text { recompressions for } \\
\text { Type II decompression } \\
\text { sickness }\end{array}$ & $\begin{array}{l}\text { Men with previous } \\
\text { compressed air } \\
\text { experience }\end{array}$ & $\begin{array}{l}\text { Men without previous } \\
\text { compressed air } \\
\text { experience }\end{array}$ \\
\hline $\begin{array}{l}1 \\
2\end{array}$ & 6 5er cent & ${ }_{2}^{7}-4$ per cent \\
\hline 0 & $9 \quad(50$ per cent $)$ & 214 (96 per cent) \\
\hline Total . & 18 & 223 \\
\hline \multicolumn{3}{|c|}{$x^{2}=44.5$, d.f. $\quad 1, p<0.001$} \\
\hline
\end{tabular}

TABLE XIII

SHIFT AND NoN-SHIFT WORKERS WITH BONE Lesions

\begin{tabular}{|c|c|}
\hline $\begin{array}{l}\text { Without previous compressed air } \\
\text { experience (223) }\end{array}$ & $\begin{array}{lc}\text { Non-shift (28) } & \text { Shift (195) } \\
3(11 \text { per cent }) & 35(18 \text { per cent }) \\
x^{2}-0.467, p>0.3 . & \text { Not significant }\end{array}$ \\
\hline $\begin{array}{l}\text { With previous compressed air } \\
\text { experience (18) }\end{array}$ & $\begin{array}{c}\text { Non-shift (3) } \\
3(100 \text { per cent }) \quad 6(40 \text { per cent }) \\
\text { p } 0 \cdot 103 . \text { Not significant }\end{array}$ \\
\hline $\begin{array}{l}\text { With and without previous com- } \\
\text { pressed air experience ( } 241)\end{array}$ & $\begin{array}{cc}\text { Non-shift (31) } & \text { Shift (210) } \\
6(19.4 \text { per cent }) & 41(19.5 \text { per cent })\end{array}$ \\
\hline
\end{tabular}


was available about the number of decompressions, working pressures, or periods of work in previous contracts, details which might allow a full consideration of the risks to which these men had been exposed (Tables VIII and IX).

COMPARISON BETWEEN MEN WITH AND WITHOUT PREVIOUS EXPOSURE TO COMPRESSED AIR

Fifty per cent of men with a history of exposure to compressed air before the Clyde contract had bone lesions compared with only 17 per cent of those men without a history of previous exposure to compressed air (Table X).

Men with previous experience of work in compressed air had a much higher prevalence of both Type I (bends) and Type II decompression sickness during the Clyde contract than had men without previous exposure (Tables XI and XII). There was no statistically significant difference between the proportion of men with bone lesions in shift workers, who usually spend periods of eight hours in compressed air, and non-shift workers, who usually spend periods of less than four hours in compressed air (Table XIII), whether they had had experience of compressed air work previous to this contract or not.

TABLE XIV

Age Composition of the Men in the Survey

\begin{tabular}{|c|c|c|c|c|}
\hline \multirow{2}{*}{$\underset{\text { (years) }}{\text { Age }}$} & \multicolumn{2}{|c|}{$\begin{array}{l}\text { Without previous } \\
\text { compressed air experience }\end{array}$} & \multicolumn{2}{|c|}{$\begin{array}{l}\text { With previous } \\
\text { compressed air experience }\end{array}$} \\
\hline & $\begin{array}{c}\text { With } \\
\text { bone lesion }\end{array}$ & $\begin{array}{c}\text { Without } \\
\text { bone lesion }\end{array}$ & $\begin{array}{l}\text { With } \\
\text { bone lesion }\end{array}$ & $\begin{array}{c}\text { Without } \\
\text { bone lesion }\end{array}$ \\
\hline $15-19$ & 0 & 6 & 0 & 0 \\
\hline $20-24$ & 3 & 34 & 0 & 0 \\
\hline $25-29$ & 11 & 44 & 0 & 0 \\
\hline $30-34$ & 8 & 41 & 2 & 3 \\
\hline $35-39$ & 8 & 31 & 2 & 3 \\
\hline $40-44$ & 4 & 22 & 1 & 0 \\
\hline $45-49$ & 2 & 4 & 0 & 2 \\
\hline $50-54$ & 0 & 1 & 2 & 1 \\
\hline 55 and over & 2 & 2 & 2 & 0 \\
\hline Total & 38 & 185 & 9 & 9 \\
\hline
\end{tabular}

The age composition of the men in the survey is shown in Table XIV. In men without previous compressed air experience there is no significant difference in the proportion with bone lesions above the age of forty years compared with those below the age of forty years $\left(x^{2}=0 \cdot 327\right)$.

\section{SUMMARY}

Evidence from the Clyde contract suggests that: 1) the greater the number of decompressions that a man experiences the higher the risk of acquiring a bone lesion, but no evidence was obtained that the risk of acquiring a bone lesion differed between shift and nonshift workers (Table XIII); 2) lesions were more likely to occur after exposures to pressures above 30 pounds per square inch gauge; 3 ) among men without previous exposure to compressed

VOL. 48 B, NO. 2, MAY 1966 
air those who had suffered at least one attack of bends were more likely to have a bone lesion than those men who had never suffered from bends. In spite of this general relationship, the probability of having a bone lesion did not increase with the number of attacks of Type 1 decompression sickness suffered. For example, two men in the survey with no previous experience of compressed air work, each of whom had suffered from eight attacks of bends in the course of 1,622 and 1,654 exposures to compressed air, had no bone lesions.

\section{CONTROLS}

Fifty unselected men taken on at the Tyne tunnel, who, as far as could be ascertained, had had no previous experience of compressed air work, were examined radiographically as they presented themselves for shift work to determine the presence or absence of bone lesions. The radiographs were presented independently to two radiologists (F. C. G. and J. K. D.) among other radiographs of experienced compressed air workers. In none of the bones of the fifty men were any lesions of aseptic necrosis reported.

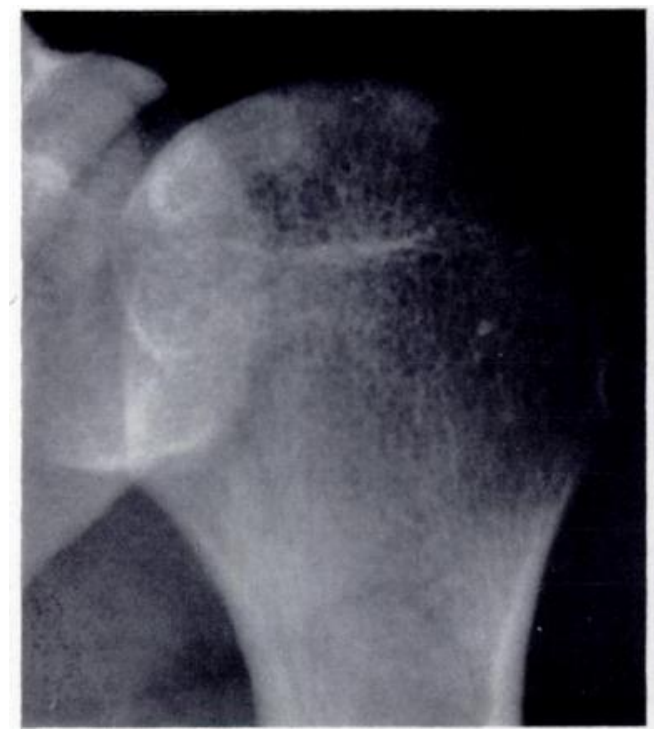

Fig. 2

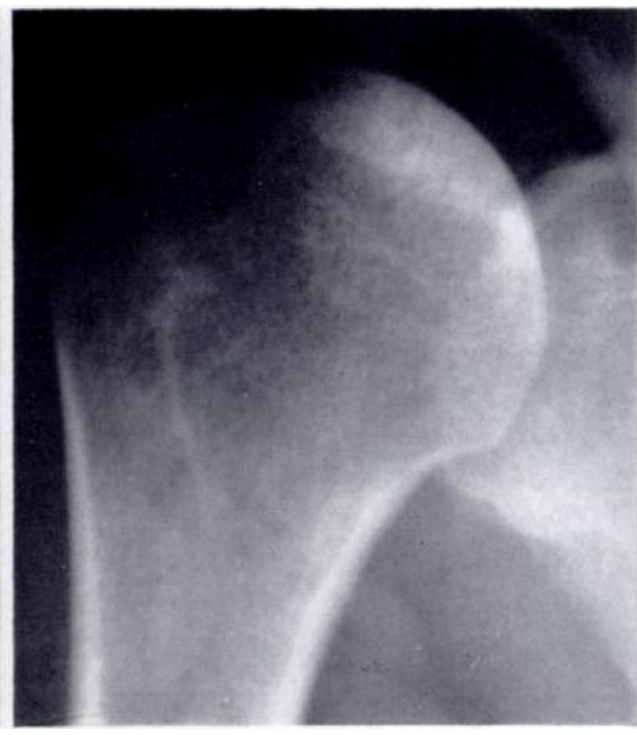

FIG. 3

Figure 2-Juxta-articular lesion. Dense areas. Figure 3-Juxta-articular lesion. Spherical segmental opacity.

The age distribution of this control group was not identical with that of the group of Clyde workers without previous compressed air experience who developed bone lesions, but, as has been shown above (Table XIV), in the latter there was no statistically significant association between age and the presence of a bone lesion.

\section{RADIOGRAPHIC FINDINGS IN THE CLYDE WORKERS}

The bone lesions seen in compressed air workers are indistinguishable radiologically from aseptic necrosis from other causes. Diagnosis is based primarily on the presence of patches of increased density in the affected area, but areas of decreased density may also be seen.

The radiographic appearances of the bone lesions in the Clyde group of men resembled some of those described in the literature. We have classified the radiographic lesions found in compressed air workers as follows. 


\section{JUXTA-ARTICULAR LESIONS}

These occur in the head of the humerus or femur, or both, and may be bilateral. They are in close proximity to the articular cortex of the bone, which may collapse with distortion or breakage of the unsupported articular cartilage. In this event symptoms may arise.

Dense areas with an intact articular cortex (Fig. 2)-These lesions are commonly found in the head of the humerus and, less frequently, in the femoral head. They are often bilateral and multiple and they appear as small dense areas close to, and often touching, the intact articular cortex. Their margins, unlike those of bone islands, are irregular and the trabeculae passing through them appear to be thickened or fused. The surrounding bone is normal.

Spherical segmental opacities (Fig. 3)-Opacities shaped like the segment of a sphere are found in the head of the humerus and less frequently in the head of the femur. This lesion appears to correspond to what Poppel and Robinson (1956) described as a "snow-cap," but their description is imprecise. At a later stage these lesions may

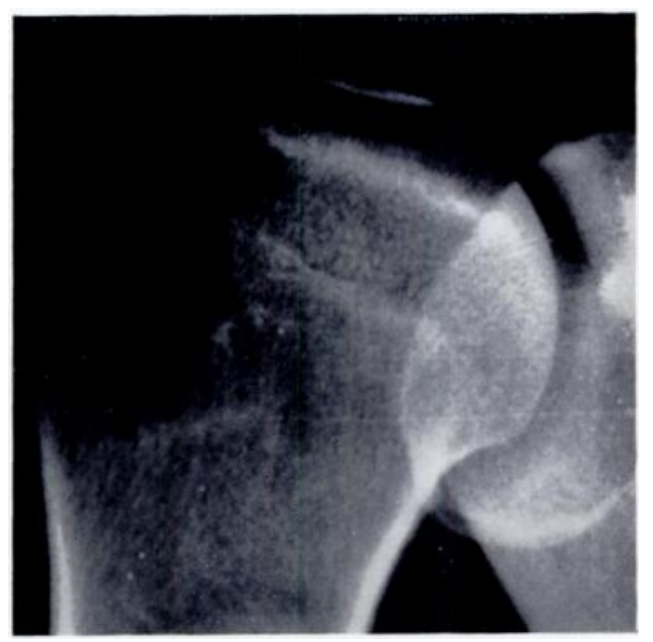

Fig. 4

Juxta-articular lesion. Rareficd area bounded by linear opacity. collapse or become sequestrated (see below).

Linear opacity (Fig. 4)-This lesion occurs commonly in the head of the humerus and rarely in the femoral head; it is sometimes bilateral. The linear opacity, which may be curved or serpiginous, varies in thickness and density. Its ends extend to the articular cortex on each

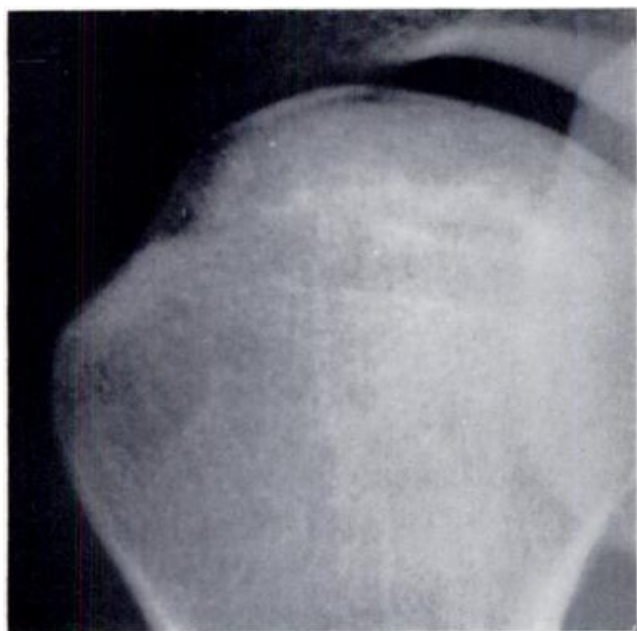

FiG. 5

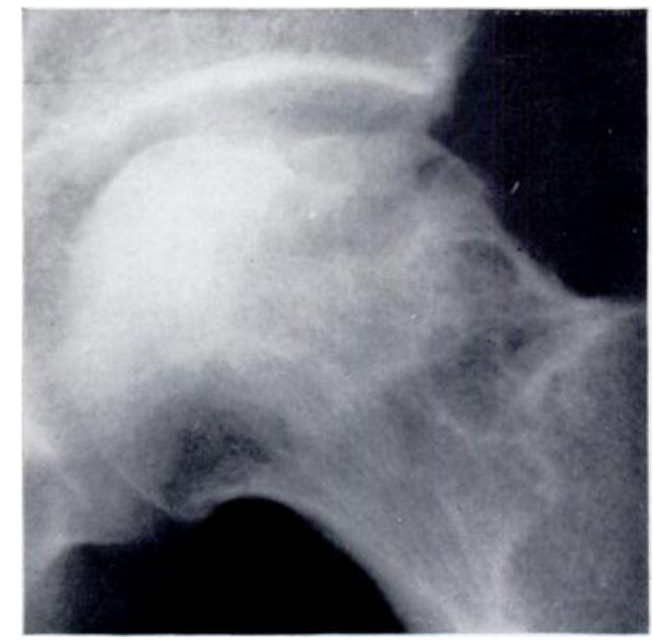

Fig. 6

Figure 5-Juxta-articular lesion. Structural failure: transradiant subcortical band. Figure 6-Juxtaarticular lesion. Structural failure: collapse of articular cortex.

side so that as much as two-thirds of the joint surface, as seen in the radiograph, is sometimes included by it. The bone between the dense layer and the articular cortex sometimes shows a decrease in density. The bone on the shaft side of the linear opacity sometimes contains small dense areas. In some cases the dense line appears to follow the old epiphysial line. 
Structural failure. Transradiant subcortical band (Fig. 5)-This lesion is found in the heads of humeri and femora, and appears as a transradiant line below the articular cortex. In some instances the transradiancy underlies as much as two-thirds of the articular surface. This transradiancy probably represents a fracture line (Norman and Bullough 1963).

Collapse of the articular cortex (Fig. 6)-Occasionally the middle third or more of the articular cortex of the head of the humerus and up to half of the articular cortex in the "weightbearing" area of the femoral head on one or both sides collapses.

Sometimes a large intact segment or several small fragments of the articular cortex sink into the subcortical bone. There is a clear "step formation " at the junction with the normal articular cortex. In the adjacent bone there is frequently a large triangular density with its apex extending towards the shaft of the bone.

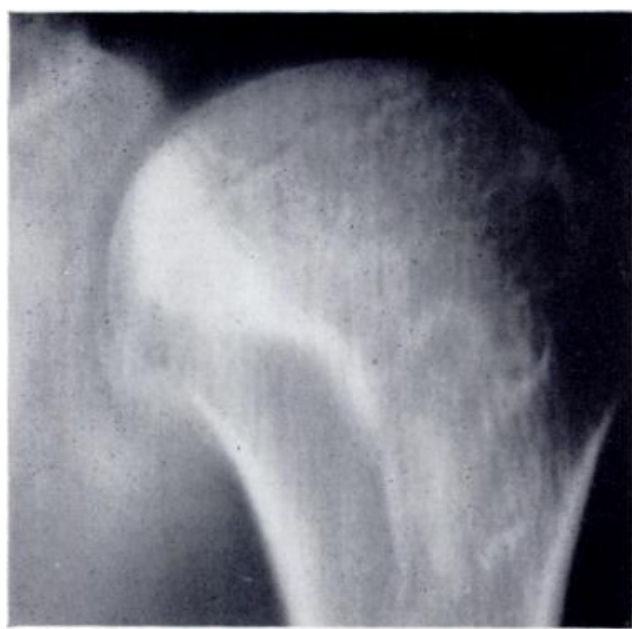

FIG. 7

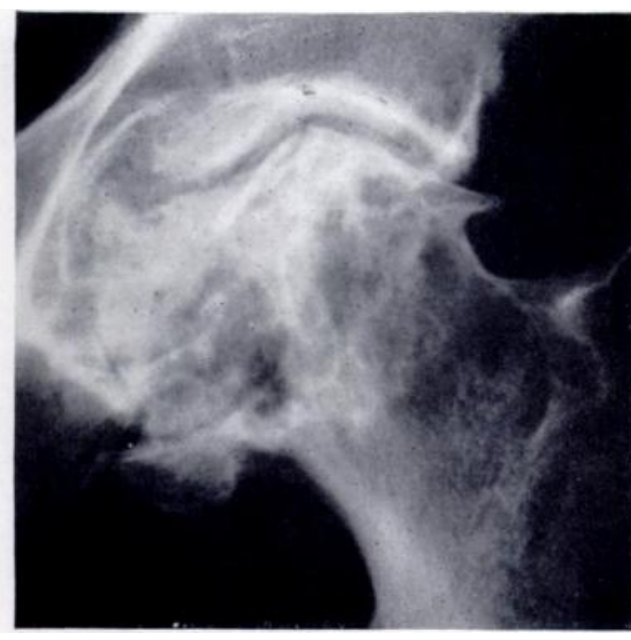

FIG. 8

Figure 7-Juxta-articular lesion (tomograph). Structural failure: sequestration of cortex. Figure 8 Juxta-articular lesion with osteoarthritis.

Sequestration of part of the cortex (Fig. 7)-A large segment of the articular cortex of the humerus or femur appears to have separated but it is not depressed below the level of the articular surface. Occasionally small fragments of articular cortex appear to be detached. The remainder of the bone head sometimes shows increased density.

Osteoarthritis (Fig. 8)-Osteoarthritis with osteophyte formation may follow aseptic necrosis involving the articular cortex of the humerus or femur when the lesion is long standing. Characteristically the glenoid and acetabulum are not affected until a very late stage and the joint space is usually of normal width.

\section{HEAD, NECK AND SHAFT LESIONS}

These are situated at a distance from the articular cortex and are believed to remain symptomless.

Dense areas (Fig. 9)-These lesions are commonly found in the neck and proximal shaft of femur and humerus. Less commonly they are present in the distal shaft of the femur or proximal shaft of the tibia. The lesions are usually multiple and bilateral. Occasionally a large area of bone is involved, but the lesions are usually small and ill-defined, and it can be difficult to distinguish between them and bone islands. A typical site for this lesion is the upper margin of the femoral neck.

Irregular calcified areas (Fig. 10)-These lesions are commonly situated in the distal shaft of the femur, in the proximal shaft of the tibia, and in the proximal shaft of the humerus. They 
are found only in the medulla. They are frequently bilateral and multiple and consist of irregularly calcified areas of varied size and distribution. In some cases they form a circular

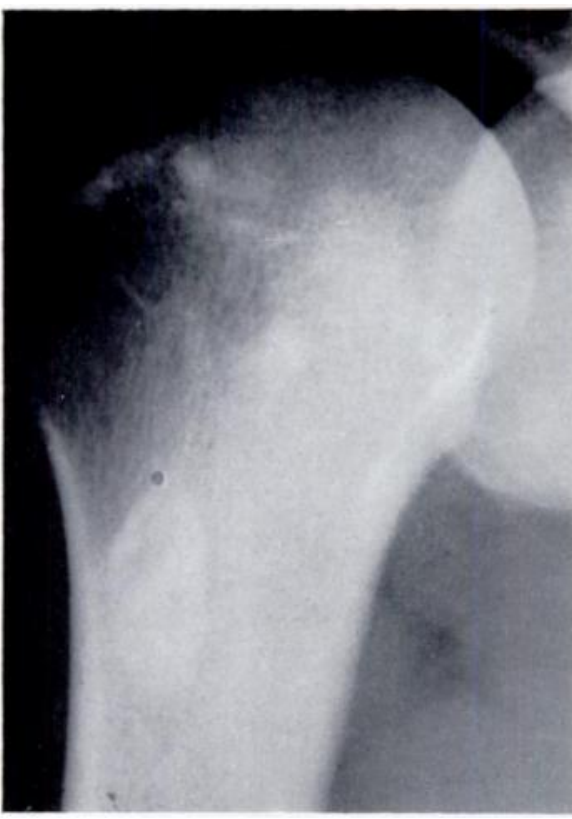

FIG. 9

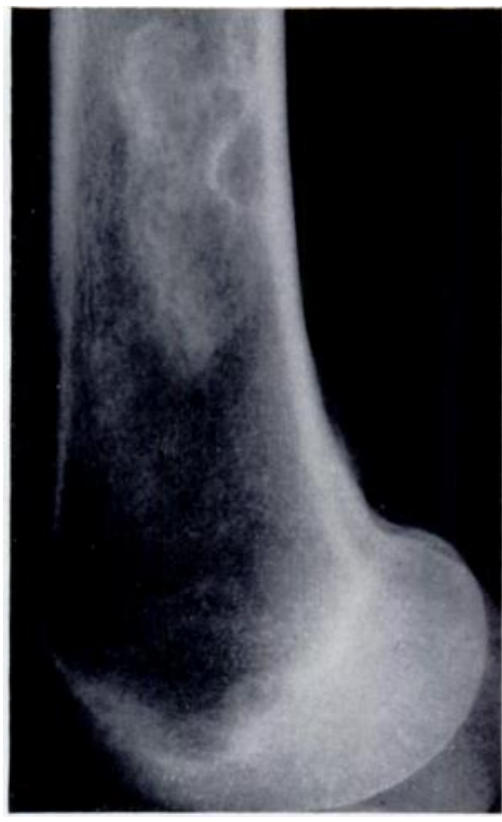

Fig. 10

Figure 9-Head, neck and shaft lesions. Dense areas. Figure 10-Shaft lesion. Irregular calcified area.

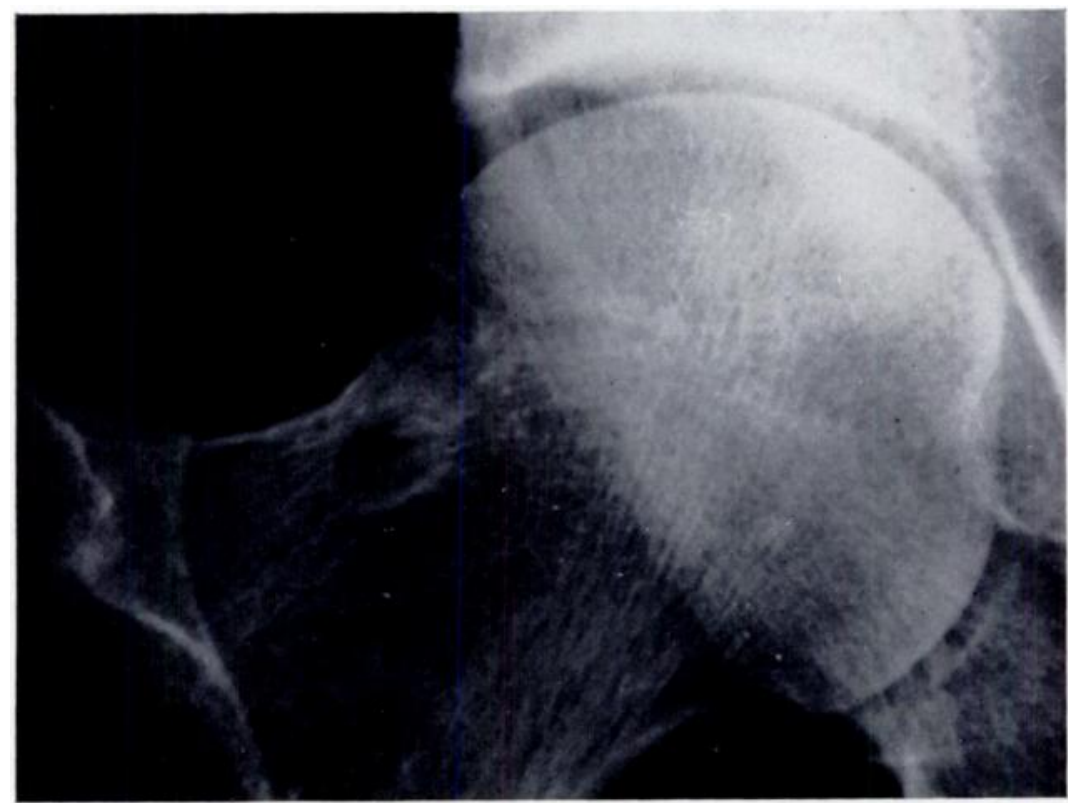

Fig. 11

Neck lesion. Cyst.

cluster and in other cases a continuous broad strip several centimetres in length with ill-defined margins. Lesions at the lower end of the femur are more clearly demonstrated in a lateral than in an antero-posterior radiograph.

VOL. 48 B, NO. 2, MAY 1966 
Transradiant areas and cysts (Fig. 11)-Transradiant areas, sometimes surrounded by a sclerotic margin in which case we have called them cysts, are found in the head and neck of the humerus and in the neck of the femur. They may be as large as two centimetres in diameter and are occasionally seen close to the articular surface of the head of the humerus or femur. When a transradiant area is situated close to the humeral cortex its margin may follow the shape of the bone. These lesions were best seen in tomographs.

\section{PATHOLOGY}

In order to interpret the radiological appearances correctly they must be correlated with the underlying histological changes.

The first histological confirmation that the radiological changes in the bones of compressed air workers were the results of aseptic necrosis was afforded by Kahlstrom, Burton and Phemister (1939). Since then further reports have been made by Phemister (1940), Walker (1940), Swain (1942), de Sèze and colleagues (1951), McCallum and colleagues (1954), and Laufer (1957). Many of these reports are brief and all of them concern patients with symptoms due to collapse of the joint surface.

In 1962 the Medical Research Council Decompression Sickness Panel obtained the left humerus and the right femur from a compressed air worker who died during treatment for decompression sickness during another contract. This case has been reported in detail elsewhere (Bennison, Catton and Fryer 1965). Although this man had been employed in compressed air work for fourteen years, he had never complained of symptoms suggesting that he had aseptic necrosis of bone. At necropsy both bones showed a normal contour and external appearances, but on section areas of necrosis were apparent in the humeral head and shaft and in the femoral head.

Death of an area of bone is recognised histologically by acellularity of the bone marrow and by absence of osteocytes in the bone lacunae. When revascularisation occurs the marrow may return virtually to normal, but recognisable unresorbed dead bone cores remain for a long time in the centre of the new bone trabeculae.

Histological examination of the humeral head showed, by the presence of unresorbed dead bone in the centre of many trabeculae, that all the head had at one time been dead (Figs. 12 to 14). Much had revascularised and only a fairly shallow subchondral saucer remained necrotic. The border between necrotic and revascularised zones was marked by a band of dense fibrous tissue. The trabeculae adjacent to the fibrous tissue on the revascularised side were very broad because of the deposition of a particularly thick layer of viable bone on the surface of unresorbed dead trabeculae, and this would account for the dense linear opacity seen in this region on radiographs.

It was evident then that the initial necrosis involved a larger area than the small lesion which was identifiable in a slab radiograph. The radiographically dense boundary of the lesion represented the most proximal point to which the revascularisation process had reached. It appeared unlikely that revascularisation would have progressed further in view of the avascular collagen in this zone. Even over the unrevascularised bone the articular cartilage was viable and of normal thickness.

The lesion in the shaft of the humerus was a few centimetres below the surgical neck. It had a pale necrotic centre with a dense fibrous boundary and occupied about half the width of the medullary canal. The presence of living bone on the surface of dead trabeculae showed that the necrosis had initially involved the whole width of the spongy bone and a small part of the endosteal surface of the cortex on both sides. The lesion was scarcely detectable in a radiograph of a thin transverse slice of bone at this point.

The histological changes seen in the femoral head were similar to those in the head of the humerus (Figs. 15 to 17). Necrosis had initially involved much of the head, crossing the 
epiphysial scar, but extensive revascularisation and deposition of new bone had occurred and only a subchondral zone, chiefly in the lower part of the head, remained necrotic. Again, the revascularisation process appeared to have halted at a zone of dense fibrosis and the broad reossified trabeculae in the revascularised area resulted in an increase of radiological density. No evidence of thrombosis or recanalisation was seen in any blood vessel.

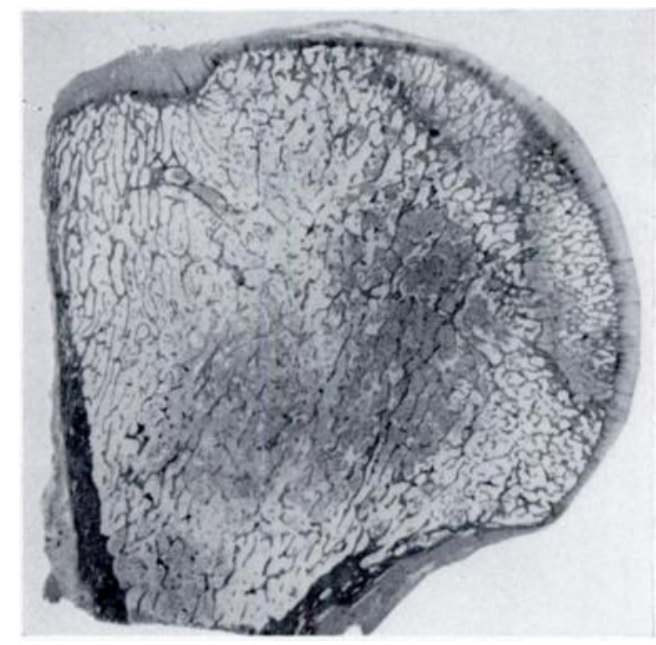

FIG. 12

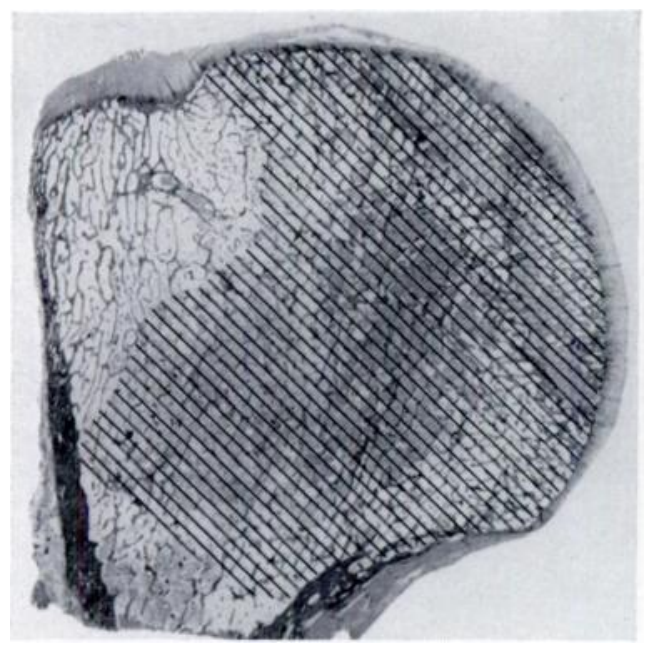

Fig. 13

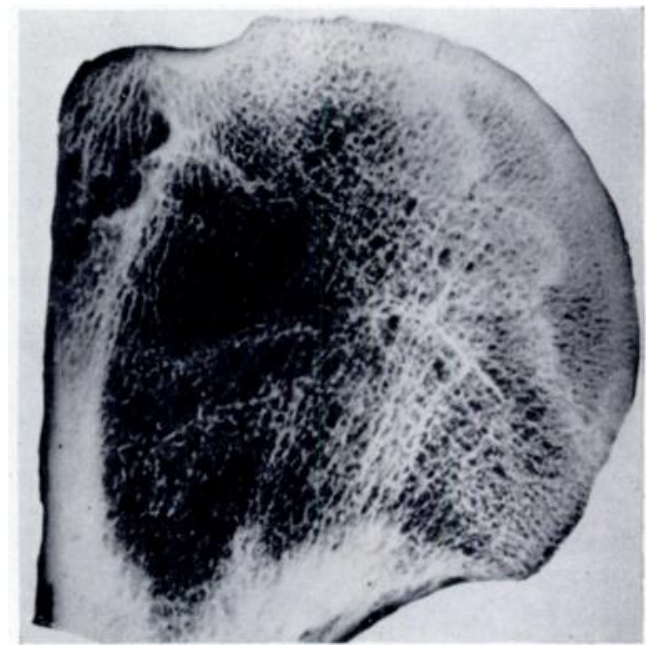

Fig. 14

Humeral head showing aseptic necrosis. Figure 12-Photomicrograph of whole humeral head. The contour of the humeral head is well preserved, the articular cartilage being of normal thickness and showing no degenerative changes. Beneath the articular cartilage there is a shallow saucer of dead bone bordered by a greyish line of fibrous tissue representing the farthest advance of the revascularisation process. Broad trabeculae are found immediately distal to this. They consist of living bone which has been laid down on unresorbed dead trabeculae. The dark material in the marrow spaces in the centre of the head consists of bone dust pushed into the marrow during sawing and is artefactual. Figure 13-The hatched area indicates the minimal extent of the original necrotic zone. Trabeculae within the revascularised area consist of dead bone covered by living bone. Figure 14-Slab radiograph. The irregular line near the joint surface represents the broad reossified trabeculae immediately behind the fibrotic revascularisation front.

In addition to the necropsy specimens described above, biopsy specimens obtained at operation were available from four Clyde tunnel workers, all of whom had severe joint symptoms with radiological evidence of collapse of a joint surface and of secondary degenerative changes. The histological appearances in these late cases in which collapse of an articular

VOL. 48 B, NO. 2. MAY 1966 
surface had occurred bore a striking resemblance to "idiopathic" bone necrosis, of which an excellent description was given by Patterson, Bickel and Dahlin (1964).

In all four patients operated upon a major part of the joint surface consisting of viable articular cartilage with an underlying fringe of dead bone had partly separated. There was evidence of some revascularisation of the necrotic bone, and where this had occurred secondary osteoarthritic changes with remodelling of the articular surface had taken place with osteophyte and "cyst" formation.

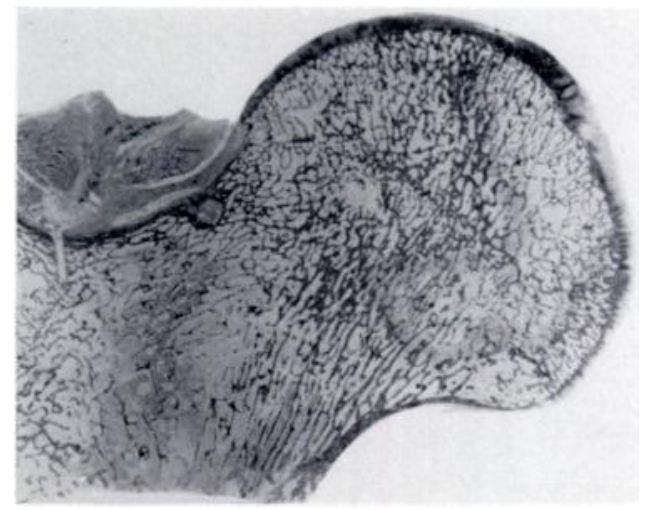

Fig. 15

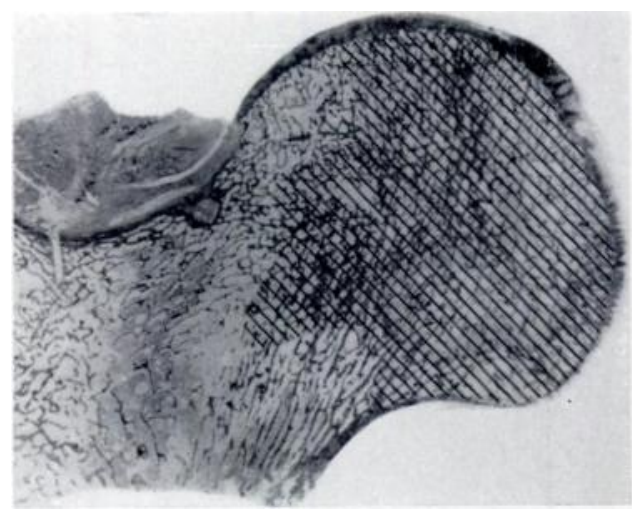

Fig. 16

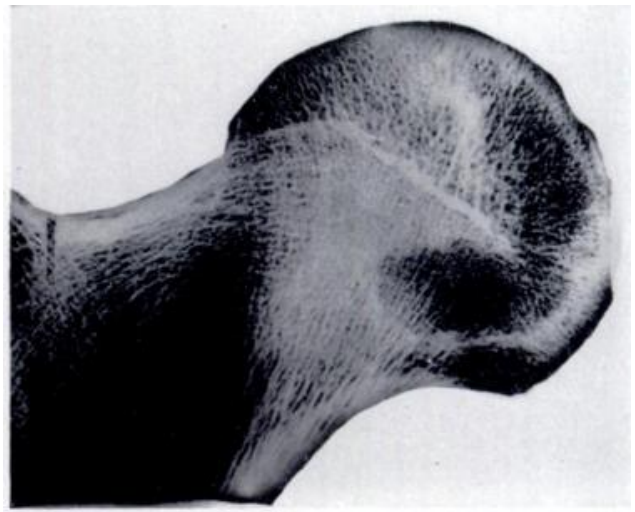

Fig. 17

Femoral head showing aseptic necrosis. Figure 15-Photomicrograph of femoral head and neck. The contour of the femoral head is unaltered and the articular cartilage of normal thickness. A zone of necrotic bone is outlined by a greyish line representing the fibrotic revascularisation front and behind this broad reossified trabeculae are seen. Figure 16-The hatched area indicates the minimal extent of the original necrotic zone. Trabeculae within the revascularised area are broader than normal due to living bone laid down on dead. Figure 17-Slab radiograph. The normal density of the necrotic bone is in marked contrast to the increased density in the revascularised zone which is especially marked at the necrotic margin.

A radiological " cyst" deep in the femoral head of one patient with a recently collapsed articular surface and no significant osteoarthritis was found to consist of a mass of granulation tissue, organising fibrin and fragments of dead bone.

There was evidence that more than one episode of ischaemia might have occurred in two patients, as shown by the presence of dead fibre bone on the surface of dead lamellar trabeculae. None of the biopsy material was heavily calcified.

In summary, then, it seems likely that not all the lesions of aseptic necrosis of bone are detectable by radiography, at least in the early stages, and that when radiographic changes are seen they may represent only a small part of the initial necrotic area. An increase of 
radiological density may be the result of deposition of new bone on dead trabeculae or of marrow calcification, though the latter was minimal in these patients.

The articular cartilage may remain viable and of normal thickness even when the bone it covers is dead. Furthermore, sequestration of part of the joint surface leads to relatively little alteration in the cartilage. The notable changes seen at the joint surface following collapse are secondary degenerative ones and occur in the viable or revascularised part of the articular cortex. Cysts seen in radiographs may be associated with secondary osteoarthritis or may represent granulation tissue, organising fibrin and fragments of dead bone.

The cause of the failure of complete revascularisation is not clear but in our cases it seemed that it was not the result of the mechanical break in the cortex, nor of heavy calcification within the necrotic area.

\section{CLINICAL FEATURES}

In our experience of the clinical features of aseptic necrosis of bone, based partly on the Clyde tunnel group of men, head, neck and shaft lesions do not cause symptoms, and the juxta-articular lesions are seldom painful before there is radiographic evidence of deformation of the articular cortex. In the shoulder, symptoms may commence suddenly when, for instance, a heavy bag of tools or a baulk of timber is picked up, presumably because of collapse of necrotic trabeculae supporting the articular cortex. In some men symptoms are insidious in onset, with pain in the shoulder radiating down the lateral aspect of the upper arm to about the level of the insertion of the deltoid muscle. Pain is commonly present in the shoulder when the patient lies in bed on the affected side.

When there is only slight deformation of the articular surface a full range of movement in the shoulder is usually retained, and the only abnormal physical signs are a painful arc of movement between 60 and 180 degrees of abduction, and difficulty in maintaining right-angled abduction of the upper arm against resistance. The clinical picture resembles that of a degenerative lesion of the shoulder cuff.

After collapse of the articular surface of the humeral head osteoarthritic changes develop and progressively restrict all movement of the shoulder joint.

Juxta-articular lesions in the hip rarely give rise to an acute onset of pain in the joint. The initial symptom is usually pain over the anterior aspect of the hip joint or trochanter radiating down the antero-lateral aspect of the thigh to the knee. The pain may at first be thought to be mild bends by the man if he is still engaged upon compressed air work, but it is not relieved by recompression. After a time the pain becomes more severe and may interfere with sleep. Later, movement at the hip is restricted, especially abduction and rotation. A useful range of flexion is usually retained, even when there are severe deformation of the articular cartilage of the head of the femur and associated arthritic changes in the joint.

\section{TREATMENT}

Four of the men in this survey with juxta-articular lesions, one in the femur and three in the humerus, were treated surgically to alleviate pain because there appeared to be no reasonable prospect of restoring the joints to normality by prolonged rest and traction. In all of these the radiographs taken before operation showed considerable deformation and collapse of the articular cortex. In each case there was a narrow transradiant band running through the subcortical bone a few millimetres below the articular surface.

At operation on these patients the depressed area of articular cartilage was seen to have lost its sheen and to be pale yellow in colour. It could be detached, together with a narrow zone of necrotic bone, from the remainder of the head at the level of the transradiant band seen on the radiograph. Deep to the line of cleavage there was a zone of necrotic bone of varying depth overlying a layer of dense avascular fibrous tissue.

vOL. 48 B, NO. 2, MAY 1966 
With the object of promoting revascularisation and healing of the overlying necrotic bone a number of holes were drilled through the avascular layer in each case. Although this manoeuvre has not resulted in any improvement in the range of movement of the affected joints it has reduced pain. For instance, one man who had a painful shoulder with limited movement now has less pain and is able to work as a builder's labourer. In the man with the juxta-articular lesion affecting the femoral head there was also a large cavity lined by granulation tissue. This was packed with cancellous bone autografts and, in addition, holes were drilled through the avascular layer. Although there has been no increase in the range of hip movement the joint is less painful and the patient is able to work as a baker.

\section{DISCUSSION}

Prevalence of aseptic necrosis in compressed air workers-Estimates of the prevalence of aseptic necrosis in compressed air workers vary from zero (Lewis and Paton 1957) to 75 per cent (Bell, Edson and Hornick 1942). The main problems in determining the total number of men affected by aseptic necrosis of bone are 1) that in practice it is very difficult to radiograph all the men at risk; and 2) that repeated radiological examination for several years after work in compressed air ceases is necessary if all the affected men are to be detected.

The exact time at which the earliest radiographic evidence of aseptic necrosis appears after the causative exposure to compressed air is not known, but one man in this survey was found to have a bone lesion three months after starting work in compressed air. In most cases it is not possible to identify the particular exposure responsible for the lesion except when a lesion has followed a single exposure. Many lesions cause no symptoms for a long time and may never give rise to symptoms, so that such lesions will not be detected unless specifically looked for. In our experience the early radiographic changes of aseptic necrosis can easily be missed until attention is drawn to them by more marked changes in later radiographs.

Studies of groups of compressed air workers suffer from the fact that in this type of civil engineering work there is often an exceptionally high turnover of the labour force, due partly to the arduous nature of the work and the dangers of the environment, and partly to the fact that a high proportion are itinerant labourers who have no permanent home. For example, at the Dartford tunnel (Golding and colleagues 1960), although never more than 320 men were at work in compressed air at any one time, 1,200 compressed air workers were actually employed. At the Clyde tunnels 55 per cent of the men left after less than four months and 20 per cent after less than one month.

The 241 men included in the present survey were those remaining in employment towards the end of the contract in which a total of 1,362 compressed air workers had been employed. Forty-seven men (19 per cent) of the 241 showed radiographic evidence of aseptic necrosis of bone. Most of these lesions appear to have been acquired during this contract. Some men who only stayed for a few months and underwent relatively few decompressions nevertheless contracted aseptic necrosis of bone (Table II).

It can be expected that some of the 1,121 compressed air workers employed on the Clyde tunnels who were not included in this survey will also have acquired bone lesions, either during this contract or during previous work on a compressed air contract. In fact, it is known that up to May 1964 eleven of them have presented with disabling aseptic necrosis of bone at Glasgow hospitals.

If the men in our survey can be regarded as a representative sample then we could expect that about 19 per cent or approximately 250 of all the men who were at risk will have bone lesions. On the other hand, if there are no more men with bone lesions than those found to date (forty-seven in the survey and eleven since) the overall prevalence would be 4 per cent. Therefore, the prevalence of aseptic necrosis of bone in this contract up to the present date 
is from 4 per cent to 19 per cent. As time elapses it can be expected that the number of bone lesions detectable radiologically in this group of men will increase.

These figures refer to all lesions, whether juxta-articular or in the head, neck and shaft of bone, but it is clear that the juxta-articular lesions are the more important clinically in that they may lead to disability. Of these, femoral juxta-articular lesions will probably lead to more severe disability than juxta-articular lesions in the humerus. In our survey 4 per cent of the 241 men had femoral juxta-articular lesions (three men having both sides affected) and 6 per cent had humeral juxta-articular lesions (six men having both sides affected).

Diagnosis and differential diagnosis-In this survey bone radiographs have been confined to the head and upper end of the humerus, head and upper end of the femur, lower end of the femur and upper end of the tibia for two reasons: 1) there was a limit to the time that could be spent on radiographing each individual, and 2) experience has shown that these are the common and most important sites for this type of lesion, although it is recognised that other sites, such as the shaft and lower end of the humerus, the tibia, the fibula, the ischio-pubic ramus, the acetabulum and the clavicle may also be affected (Bell, Edson and Hornick 1942).

The radiographic changes of aseptic necrosis of bone seen in compressed air workers must be differentiated from those of Gaucher's disease, sickle-cell anaemia, the arthropathy of steroid therapy, osteochondritis dissecans and the changes following dislocation or fracture. These conditions as well as calcified enchondromata and osteoblastic metastases, may have to be excluded by a careful study of the patient's history and by clinical tests. Idiopathic necrosis of the femoral head in adults (Merle d'Aubigné 1964) is considered to be a rare condition in Great Britain, and aseptic necrosis, when it occurs in a man with a history of exposure to compressed air, may, in our opinion, reasonably be attributed to his work if other causes can be excluded. The lesions of aseptic necrosis in compressed air workers are often multiple and bilateral. Analysis of the figures in Table I shows that using the $x^{2}$ test the likelihood of this symmetrical occurrence of lesions being due to chance is remote $(p<0.001)$.

It is usually still possible to detect the underlying characteristic changes of aseptic necrosis, even when they are complicated by secondary osteoarthritis. Under these circumstances the width of the joint space as seen in the radiograph is usually unaffected because the cartilage retains its normal thickness until late in the disease.

Some difficulty may be experienced in differentiating dense areas of aseptic necrosis of bone from the bone islands which are commonly found in the normal skeleton. Bone islands are usually composed of uniformly dense compact bone and are ovoid or oblong in shape (Kim and Barry 1964), whereas the lesions of aseptic necrosis tend to be irregular in shape and to have thickened trabeculae running through them (Reboul and colleagues 1955, Fournier and Jullien 1959, Mosinger and Jullien 1961). Tomography may help in differentiating between bone islands and aseptic necrosis by demonstrating the irregular outline of the latter.

In this survey radiographs showing areas of bone with only slight thickening of the trabeculae have been classified as normal but it is hoped to re-examine radiographically these areas later to see whether they develop into typical lesions of aseptic necrosis.

Etiology-It is obviously of paramount importance to know the factors which determine the risk that a man may acquire a bone lesion if this risk is eventually to be eliminated. A relationship has been shown between the number of decompressions and the prevalence of bone lesions (Table IIB), as well as between the maximum pressure experienced and the prevalence of bone lesions (Table III).

It is unfortunate that in the analysis of the data from the Clyde contract we have not found it possible to separate the effect of the number of decompressions to which a man has been subjected from those of the pressure at which he worked. In our sample the men who experienced pressures over 30 pounds per square inch gauge were also the men who had been employed the longest and therefore decompressed the most frequently (Fig. 1). It is hoped that separation of these two factors may be possible in the future using data from other contracts.

vOL. 48 B, NO. 2, MAY 1966 
Pathogenesis-The usual explanation for the occurrence of aseptic necrosis of bone in compressed air workers is that during or after decompression bubbles of nitrogen arise in the blood and tissues, obstruct blood vessels and thus cause infarction. Campbell and Hill (1933) showed that in goats there was a slow rate of saturation of bone marrow with nitrogen. This, they claimed, was due to a "low circulation rate through marrow" and a " high fat content diminishing the rate of diffusion." Presumably in bone marrow there is also a slow rate of desaturation which would predispose towards the risk of both intravascular and extravascular nitrogen bubble formation during decompression after a prolonged exposure to compressed air. In man, areas of necrosis in the rigid tissue of bone might thus follow local interruption of its blood supply by bubbles within or without the vessels.

As the head of the humerus and the head of the femur are so frequently affected by aseptic necrosis in man it is tempting to suggest that posture is a factor. Thus, it could be argued 1) that because of gravity the upper end of a bone has a poorer blood supply than the lower end, and 2) that intravascular or extravascular bubbles within the cavity of bone might show a tendency to rise to the highest point before causing obstruction to the blood supply. On the other hand, lesions frequently occur in the lower end of the femur, and it would be difficult to explain these on this hypothesis unless it could be established that during decompression the affected men sat with their knees above the level of their hips.

However, direct evidence in support of the hypothesis that aseptic necrosis of bone in man is caused by infarction by gas emboli is lacking.

Experiments on animals in which air emboli were produced by injection (Kahlstrom, Burton and Phemister 1939), or gas bubbles induced by rapid decompression from very high pressures (Gersh 1945; Colonna and Jones 1948; Averyanov and Mikhailov 1962; Antopol, Kalberer, Kooperstein, Sugaar and Chryssanthou 1964), have not succeeded in producing lesions of aseptic necrosis of bone comparable to those found in man. In any case it is doubtful whether conclusions drawn from animals completely dissimilar to man in size and rate of metabolism, exposed to pressures well beyond the usual range normally employed in compressed air work and decompressed at very high rates, can be expected to throw light on the causation of aseptic necrosis in man.

Experimental evidence of the occurrence of bone infarction following embolism by agents other than gas bubbles is also difficult to find, but Kistler (1934) produced infarction in the femora of rabbits by embolism from the injection of gum acacia suspension of charcoal into the nutrient arteries.

Another possible approach to the problem of the pathogenesis of aseptic necrosis of bone in compressed air workers may be to look for factors common to it and to aseptic necrosis of bone associated with other conditions such as steroid therapy, sickle-cell anaemia, Gaucher's disease and aplastic anaemia.

The relationship between bends and bone lesions-By showing a statistical relationship between a bone lesion and attacks of bends we have confirmed the findings of Rózsahegyi and Fried (1963), but the following factors must be taken into consideration: 1) The diagnosis and treatment of the bends depends on the affected man reporting his symptoms and on their being judged to merit treatment. Men are not paid for the time spent under treatment in the medical recompression chamber and if they do not wish to report for treatment but prefer to put up with the pain or to relieve it by taking analgesics or alcohol, then there is no record of the attack. 2) Experience suggests that almost every shift worker exposed to pressures above 16 pounds per square inch gauge at some time or another suffers from a mild attack of bends which is not sufficiently severe to make him return for recompression and which he calls the "niggles." The differentiation between what is called the "niggles" and what is called the " bends" depends on a subjective judgement. For these reasons it must be assumed that every compressed air worker has probably suffered at some time or another from untreated mild bends. From the results of this survey we conclude that a bend severe enough to call for 
treatment, even though it receives treatment, is a more likely precursor of bone necrosis than an untreated bend.

In the Clyde workers who had had no compressed air experience before this contract, 45 per cent of those with a bone lesion had been treated for the bends by the time the investigation was made. Thus the treatment of a bend does not necessarily prevent the onset of subsequent bone lesions. On the other hand, it is also possible that the bone lesions in these men arose from mild bends for which they did not receive recompression treatment.

Another factor which might reduce the closeness of the relationship between a bone lesion and the bends is the possibility that some bone lesions may result from interference with the bone circulation by symptomless bubbles, but at the moment we can neither confirm nor deny this suggestion.

Bone lesions and shift lengths-Aseptic necrosis of bone is rare in divers and this may be related to the fact that they spend much briefer periods under pressure than compressed air workers. It might be concluded from this that one way of avoiding bone lesions in tunnel or caisson workers would be greatly to shorten the shifts.

Tunnel workers who regularly spend six to eight hours in compressed air seem to be more prone to suffer from bends than men who are employed on a non-shift basis, such as electricians, carpenters and engineers, who usually spend periods of less than four hours in compressed air. For example, during the construction of the Dartford tunnel under the Thames (pressure range 18-28 pounds per square inch gauge) the bends rate on the Kent side was 1.03 per cent for men working for periods of over four hours daily and 0.05 per cent for men working for periods of under four hours daily (Golding and colleagues 1960) a difference of 0.98 per cent. It was found, however, that in the Clyde contract, in which the pressure varied from 18-32 pounds per square inch gauge, men with over four hours exposure to compressed air had a bends rate of 0.30 per cent whereas men with less than four hours in compressed air had a rate of 0.24 per cent, a difference of only 0.06 per cent. The proportion of men with bone lesions in shift and non-shift workers was the same (Table XIII), so that there is no confirmation from the Clyde investigation that limiting exposure to compressed air to four hours or less diminishes the risk of acquiring a bone lesion.

In 1936 the British Institution of Civil Engineers suggested a split shift system in which two spells of work in compressed air are separated by a period in free air. A system of split shifts was used by the Port of New York Authority in 1953 during the construction of the third tube of the Lincoln tunnel, but this did not prevent bone lesions. It is thought that the principle of the split shift system is unsound because it doubles the number of times each man is decompressed.

Prevention of bone lesions-It has recently become obvious that bone necrosis is a major hazard in compressed air work since it may lead to permanent disability if it affects the articular surface of the head of the femur or humerus. The prevalence of bone lesions is a much more realistic measure of the success of any particular decompression procedure than the bends rate.

Use of the present British Decompression Table (Ministry of Labour and National Service 1958) does not prevent bends, as rates of up to 4 per cent occur (Lewis and Paton 1957), but even if the decompression procedure was altered in such a way that bends were completely prevented there is no guarantee that bone lesions would be prevented.

There is no evidence that lengthening the decompression times given in the Decompression Table is harmful (Paton and Walder 1954), and on the Clyde, because it was noticed early in the contract that the bends rate was increasing when the pressure rose above 26 pounds per square inch gauge, the decompression times were increased by amounts varying from four to thirteen minutes, an average of seven minutes.

The overall bends rate on the Clyde was 0.29 per cent, which is better than, for example, that of the Dartford tunnel contract where it was 0.55 per cent and the Blackwall tunnel contract where it was 1.05 per cent. The proportion of attacks of severe decompression sickness

vol. 48 B, NO. 2, MAY 1966 
(Type II) in men working at 18 pounds per square inch and above on the Clyde was similar to that at Dartford and at Blackwall, being 0.0441, 0.0390 and 0.0421 per cent respectively. In spite of the apparent improvement in the bends rate in comparison with previous contracts, a large number of bone lesions were detected among men whose experience in compressed air was confined to this contract.

At present strict adherence to the British Decompression Table does not prevent the onset of aseptic necrosis of bone, nor is there any clear indication of how it can be prevented.

Management and treatment-This radiographic survey of compressed air workers revealed many symptomless but potentially disabling bone lesions which might not otherwise have been detected for some considerable time. The advice which should be given to a compressed air worker with a view to preventing future disability from a symptomless lesion must be considered, as well as the question of the advisability of such a man continuing to work in compressed air once he has developed a bone lesion.

We have no evidence to enable us to assess the probability that a man with one or more bone lesions will suffer from additional bone damage in the form of fresh lesions or extension to existing lesions if he continues to work in compressed air, and this should be made clear to a man who already has one or more bone lesions.

If a man has symptomless juxta-articular aseptic necrosis in the head of one femur it seems reasonable to advise him to avoid any further exposure to compressed air on the grounds that although the risk of developing juxta-articular aseptic necrosis in his other femoral head may be small, the consequences of such an event could be grossly disabling.

If a juxta-articular bone lesion, particularly of the head of the femur, has progressed to give symptoms, it is likely that because of the pain the man will be unable to continue to work in compressed air and will seek treatment.

Our knowledge of the evolution of the bone changes of aseptic necrosis in compressed air workers is too meagre to enable us to define a programme of treatment for all cases. Head, neck and shaft lesions have not so far given rise to symptoms in this group of Clyde workers, so that the question of their treatment has not arisen.

Juxta-articular lesions, however, present a difficult therapeutic problem. These lesions are usually symptomless until deformation of the articular surface occurs from collapse of the underlying necrotic bone, probably as a result of the stress to which it is normally subjected. The changes are most severe in the weight-bearing area of the head of the femur, and in that part of the head of the humerus which is opposite the glenoid fossa when the arm is in a position of approximately right-angled abduction. Following deformation of the articular surface, pain on movement is a prominent symptom which becomes more severe if osteoarthritic changes supervene in the damaged joint. These observations suggest, firstly, that it is that part of the necrotic bone subjected to the greatest stress which collapses, and, secondly, that this might be avoided if the joint surfaces were protected from stress by traction and rest until repair of the necrotic bone had taken place. If the radiographic appearances are an accurate index of the process of repair, then the complete restoration to normal of necrotic bone may require many years of treatment, if indeed it can ever occur.

At present no surgical treatment has been shown to be entirely satisfactory: even though pain is relieved the results are either of a temporary nature or leave the man with some permanent disability.

The suitability of the following surgical procedures has to be considered.

Stimulation of repair-A technique which seems to offer the best prospect of success is that recommended by Phemister (1949) and by Bonfiglio and Bardenstein (1958) for the treatment of avascular necrosis of the femoral head complicating transcervical fractures of the femur. Bonfiglio and Bardenstein claimed satisfactory results in three-quarters of their patients. In this operation two holes, each one centimetre in diameter, are drilled under radiographic control from the subtrochanteric area of the femur into the necrotic part of the head. An 
autogenous bone graft is driven into position along each hole so that one end of the graft lies immediately beneath the weight-bearing articular surface of the femoral head. These grafts, by breaking down the fibrous barrier between living and dead bone, may aid the advance of revascularisation into the necrotic zone. At the same time the grafts support the weakened part of the articular surface of the femoral head. Full weight bearing is not allowed until about twelve months after this operation but partial weight bearing may be allowed earlier.

If conservative surgery of this type were to have any prospect of success in compressed air workers with aseptic necrosis it would have to be undertaken well before the onset of symptoms. This would necessitate the regular radiographic examination of the femoral and humeral heads of men working in compressed air in order to detect early bone changes. Another difficulty would be that, as we have no evidence that all juxta-articular bone changes necessarily progress to give disability, it would be difficult to decide which patients required surgical treatment.

Arthrodesis-Arthrodesis is a suitable procedure for patients who have collapse of the articular cortex with secondary osteoarthritic changes affecting only one femoral head. It is probably the best operation for a fit and active man who wishes to return to moderately heavy work. If necrosis of the head of the femur is extensive, arthrodesis may be difficult to achieve and the insertion of a metallic prosthesis may be more satisfactory.

Insertion of prosthesis-When both femoral heads are involved the insertion of metallic prostheses is the best procedure if the patient is seriously disabled. In most patients the initial result is satisfactory, but it may not remain so. McCallum, Stanger, Walder and Paton (1954) reported the case of a compressed air worker with juxta-articular aseptic necrosis in both femoral heads, each of which was replaced by an acrylic prosthesis. The result was satisfactory for about three years, but further surgical treatment then became necessary. The modern metallic prosthesis is a better appliance than that used in 1952 but it may not be able to withstand indefinitely the stresses and strains of weight bearing in a heavy, active man.

Osteotomy-Osteotomy is not recommended for patients with juxta-articular aseptic necrosis of the head of the femur. It does not result in revascularisation of the necrotic area and further collapse and deformity of the weight-bearing surface of the head of the femur is inevitable.

Recommendations for the future-In order to obtain a clearer picture of the whole problem of decompression sickness and in particular of aseptic necrosis of bone in compressed air workers employed in civil engineering projects, some systematic means of acquiring data on the health of this unstable occupational group is required. In the past only limited information about specific contracts or individuals affected by bone necrosis has been obtained. What is now required is a continuous record of the medical history and compressed air experience of each worker over a period of years as he moves from job to job. For example, periodic radiographic examination of the bones of these men should be carried out. This is of increasing importance as it becomes evident that the success or otherwise of decompression procedures must be judged by the proportion of men subsequently found to have bone lesions.

Radiographic examinations of compressed air workers are already being carried out by the Medical Research Council Decompression Sickness Panel with the cooperation of civil engineering contractors.

The maintenance of adequate records of compressed air workers is extremely difficult because of the high turnover of labour and the peripatetic tendencies of the men who undertake this type of work, but a central registry to collect the medical and other relevant confidential information about these men has now been established by the Medical Research Council in the University of Newcastle upon Tyne, England.

VOL. 48 B, NO. 2, MAY 1966 


\section{SUMMARY}

1. A radiographic investigation of a group of 241 men who had worked in compressed air at pressures up to 35 pounds per square inch gauge on the construction of tunnels under the River Clyde showed that forty-seven men (19 per cent) had one or more lesions of aseptic necrosis of bone.

2. The radiological lesions have been classified as juxta-articular, which may lead to pain and limitation of movement, and head, neck and shaft lesions, which are usually symptomless. In 10 per cent of the men the lesions were juxta-articular and therefore potentially disabling. The treatment of juxta-articular lesions is described and reviewed.

3. The environmental factors associated with the occurrence of aseptic necrosis of bone, the radiological and histological appearances, and the pathogenesis of the lesions are discussed. Bone lesions were found to be related directly to the number of times a man had been decompressed, to the height of pressure at which he had worked and to attacks of bends for which treatment was given.

4. When the histological and radiographic appearances of aseptic necrosis of bone in compressed air workers are compared it is clear that a radiograph may not always reveal the full extent of the lesion, and some lesions may not show up at all. The cause of the necrosis is obscure because experimental and direct evidence of bone infarction by gas bubbles is lacking.

5. The currently accepted decompression procedures and treatment of bends used in civil engineering practice, do not prevent the occurrence of aseptic necrosis of bone in compressed air workers.

6. It is suggested that periodic radiological examination of the bones of compressed air workers should be carried out and the results correlated with other information about the men and the contracts on which they have worked in order to elucidate the causative factors in aseptic necrosis of bone. A central registry has been set up by the Medical Research Council in the University of Newcastle upon Tyne to fulfil this function.

The expenses of this investigation were defrayed by the Medical Research Council. Our thanks for cooperation and assistance are due to Sir William Halcrow \& Partners, Consulting Engineers; Messrs Charles Brand \& Son Ltd., Contractors (in particular Mr A. F. Haxton, Director, Mr H. E. Whyte, Agent, and Mr J. D. Mitchell, Safety Officer): and Dr W. Henderson and partners, Medical Officers to the Clyde Tunnel Contract.

For statistical advice and for the computer analysis we are indebted to Dr D. J. Newell, Reader, and Mrs D. Weightman, Statistical Assistant, of the Biostatistics Section of the Nuffield Department of Industrial Health, Dr E. S. Page, Director of the Computing Laboratory, Mr W. G. Leslie. Chief Technician, Department of Surgery, all of the University of Newcastle upon Tyne, and to Mr R. A. McNay, Statistician, and the Newcastle Regional Hospital Board. Radiological facilities were made available to us at the Southern General Hospital, Glasgow, and we are grateful to the radiographic staff there for their help.

One of us (W. D. M. P.) is grateful to Mr V. A. J. Swain for the opportunity of discussions with him.

\section{REFERENCES}

Allan, J. H. (1943): Decompression Disease of Bone. Journal of Aviation Medicine, 14, 105.

ANGeI, A., and Cossu, R. (1954): Infarto osseo (contributo clinico-radiologico). Archivo di Radiologia, 3, Fascicolo 3, 20.

antopol, W., Kalberer, J., Kooperstein, S., Sugaar, S., and Chryssanthou, C. (1964): Studies on dysbarism. I. Development of decompression syndrome in genetically obese mice. American Journal of Pathology, 45, 115.

Averyanov, V. A., and Mikhailov, P. M. (1962): On the cause and prevention of osteoarticular disorders in decompression (caisson) disease. Gigiena truda $i$ professional'nȳe zabolevaniya, 6, 25.

Balestra, G., and Molfino, F. (1949): Le alterazioni ossee ed osteoarticolari nelle malattie dei cassoni. Radiologia Medica, 35, 987.

Barbara, M., and Isola, A. (1939): Accademia medica, 7, 607.

Cited by Roche, L., and Rayneau, G. (1953): Les ostéo-arthropathies chez les ouvriers travaillant en air comprimé. Archives des maladies professionnelles, de médecine du travail et de sécurité sociale, 14, 233.

BAssoe, P. (1913): The Late Manifestations of Compressed-air Disease. American Journal of the Medical Sciences, 145, 526. 
Bell, A. L. L., Edson, G. N., and Hornick, N. (1942): Characteristic Bone and Joint Changes in Compressedair Workers: a Survey of Symptomless Cases. Radiology, 38, 698.

Bennison, W. H., CAtton, M. J., and Fryer, D. I. (1965): Fatal Decompression Sickness in a Compressed-air Worker. Journal of Pathology and Bacteriology, 89, 319.

BerRY, C. A., and Hekruis, G. L. (1960): X-ray Survey for Bone Changes in Low-pressure Chamber Operators. Aerospace Medicine, 31, 760.

Bétoulières, P., and Boulouys, J. (1952): Sur 3 cas d'infarctus osseux. Presse Médicale, 60, 344.

Bonfiglio, M., and Bardenstein, M. B. (1958): Treatment by Bone-grafting of Aseptic Necrosis of the Femoral Head and Non-union of the Femoral Neck (Phemister Technique). Journal of Bone and Joint Surgery, 40-A, 1329.

Bornstein, A., and Plate, E. (1911): Úber chronische Gelenkveranderungen, enstanden durch Presslufterkrankung. Fortschritte auf dem Gebiete der Röntgenstrahlen und der Nuklearmedizin, 18, 197.

Bourret, J., Fraisse, P., and Fraisse, H. (1948): La maladie des caissons: contribution à l'étude des lesions ostéo-articulaires des tubistes. Archives des maladies professionnelles, de médecine du travail et de sécurité sociale, 9, 309.

BuCKY, N. L. (1959): Bone Infarction. British Journal of Radiology, N.S. 32, 22.

Bureau, R., Horeau, M. and Lemeillet, Y. (1955): A propos de quartorze observations d'arthroses barotraumatiques. Semaine des hôpitaux de Paris, 31, iii, 2342.

Campbell, J. A., and Hill, L. (1933): Studies in Saturation of the Tissues with Gaseous Nitrogen. 1. Rate of Saturation of Goat's Bone Marrow in vivo with Nitrogen During Exposure to Increased Atmospheric Pressure. Quarterly Journal of Experimental Physiology, 23, 197.

Cavigneaux, A., Charles, A., Fuchs, S., and Tara, S. (1949): Les lésions osseuses ignorées des tubistes. Archives des maladies professionnelles, de médecine du travail et de sécurité sociale, 10, 359.

Charles, A., Cavigneaux, A., Fuchs, S., and Tara, S. (1948): L'ostéo-arthrite évolutive de la hanche chez les "tubistes." Archives des maladies professionnelles, de médecine du travail et de sécurité sociale, 9, 428.

Coburn, K. R. (1956): Preliminary Investigation of Bone Change Associated with Decompression Sickness. Journal of Aviation Medicine, 27, 163.

Coley, B. L., and Moore, M., Jun. (1940): Caisson Disease with Special Reference to the Bones and Joints. Annals of Surgery, 111, 1065.

Colonna, P. C., and Jones, E. D. (1948): Aeroembolism of Bone Marrow; Experimental Study. Archives of Surgery, 56, 161.

Dale, T. (1952): Bone Necrosis in Divers. (Caisson Disease.) Acta Chirurgica Scandinavica, 104, 153.

Déak, P., and Rózsahegyi, I. (1956): Osteoarthropathie der Caissonarbeiter (Befunde der ersten fünf Jahre). Fortschritte auf dem Gebiete der Röntgenstrahlen und der Nuklearmedizin, 84, 312.

DUfFNer, G. J. (1962): Decompression sickness and its prevention among compressed air workers. Report prepared for Metropolitan Engineers, Seattle, Washington, U.S.A.

Fischgold, H., Coville, R., and Doassans, P. (1948): Altération chronique des épiphyses dans la maladie des caissons. Journal de radiologie, d'électrologie et de médecine nucléaire, 29, 230.

Fournier, A. M., and Jullien, G. (1959): Aspect radiologiques de la maladie des caissons. Journal de radiologie, d'électrologie et de médecine nucléaire, 40, 529.

Francia, A., and Quaglia, C. (1959): Il contributo roentgenologico alla conoscanza ed all' interpretazione della manifestazione osteoarticolarie dei cassonisti. Minerva ortopedica, 10, 105.

FRÜND, R. (1956): Caissonkrankheit im Schultereckgelenk. Zeitschrift für Orthopädie und ihre Grenzgeheite, 87, 571.

Gaultier, M., Fournier, E., Gervais, P., and Ract, A. (1962): A propos de deux cas d'ostéo-arthrite barotraumatique à révélation tardive. Archives des maladies professionnelles, de médecine du travail et de sécurité sociale, $23,32$.

Gersh, I. (1945): Gas Bubbles in Bone and Associated Structures, Lung and Spleen of Guinea Pigs Decompressed Rapidly from High Pressure Atmospheres. Journal of Cellular and Comparative Physiology, 26, 101.

Golding, F. C., Griffiths, P., Hempleman, H. V., Paton, W. D. M., and Walder, D. N. (1960): Decompression Sickness During Construction of the Dartford Tunnel. British Journal of Industrial Medicine, 17, 167.

Guillain, G., and Grossiord, A. (1943): L'ostéoarthrite de la maladie des caissons. Paris medical, 329.

Cited by Baillargé, J., and Mérer, P. (1953): Archives des maladies professionnelles, de médecine du travail et de sécurité sociale, 14, 225.

GuITARD, J. (1953): Considerations sur les signes de début des ostéoarthrites baro-traumatiques. Archives des maladies professionnelles, de médecine du travail et de sécurité sociale, 14, 230.

Haxton, A. F., and Whyte, H. E. (1965): Clyde Tunnel Constructional Problems. Proceedings of the Institution of Civil Engineers, 30, 323.

voL. 48 B, NO. 2, MAY 1966 
Herget, R. (1948): Neuere Beobachtungen über chronische Gelenkveränderungen bei Tauchern durch Drucklufteinwirkung. Langbecks Archiv für Klinische Chirurgie, 281, 330.

Cited by RózsahegYi, I. (1956): Archiv für Gewerbepathologie und Gewerbehygiene, 14, 483.

HoRváth, F. (1958): Caisson-betegség okozta súlyos elváltzozások a combfejben. Magyar radiologia, $11,92$. James, C. C. M. (1945): Late Bone Lesions in Caisson Disease. Three Cases in Submarine Personnel. Lancet, ii, 6.

Jullien, G., Léandri, M., and Desanti, E. (1954): A propos des images radiologiques ostéo-articulaires consécutives au travail dans l'air comprimé et leur importance médico-légale. Annales de médecine légale, criminologie, police scientifique et toxicologie, 34, 180.

Kaczurba, A. (1962): Martwice kostne w przebiegu choroby kesonowej. Polski Przeglad Radiologii Medycyny Nuklearnej, 26, 9.

Kahlstrom, S. C., Burton, C. C., and Phemister, D. B. (1939): Aseptic Necrosis of Bone. I. Infarction of Bones in Caisson Disease Resulting in Encapsulated and Calcified Areas in Diaphyses and in Arthritis Deformans. Surgery, Gynecology and Obstetrics, 68, 129.

Kahlstrom, S. C., Burton, C. C., and Phemister, D. B. (1939): Aseptic Necrosis of Bone. II. Infarction of Bones of Undetermined Etiology Resulting in Encapsulated and Calcified Areas in Diaphyses and in Arthritis Deformans. Surgery, Gynecology and Obstetrics, 68, 631.

Kim, S. K., and BARRY, W. F., Jun. (1964): Bone Island. American Journal of Roentgenology, 92, 1301.

KIRJAKov, K. (1964): Chronic Occupational Diseases in Divers. Higiena, Bulgaria, 7, 75.

Kistler, G. H. (1934): Sequences of Experimental Infarction of the Femur in Rabbits. Proceedings of the Institute of Medicine of Chicago, 10, 110.

LAufer, A. (1957): Aseptic Necrosis of the Femoral Head. Journal of the Mount Sinai Hospital, New York, $24,957$.

LIESS, G. (1956): Knochen-und-Gelenkveränderungen bei der Caisson-Krankheit. Fortschritte auf dem Gebiete der Röntgenstrahlen und der Nuklearmedizin, 84, 472.

Lewis, H. E., and Paton, W. D. M. (1957): Decompression Sickness During the Sinking of a Caisson; a Study of Some Factors in the Pathogenesis of Caisson Disease. British Journal of Industrial Medicine, 14, 5.

McCallum, R. I., Stanger, J. K., Walder, D. N., and Paton, W. D. M. (1954): Avascular Necrosis of the Femoral Heads in a Compressed Air Worker. Journal of Bone and Joint Surgery, 36-B, 606.

Mauro, M. (1959): Le lesioni ossee ed articolari da malattia dei cassoni. Folia Medica (Napoli), 42, 288.

Mauro, M., and SAggese, V. (1959): Contributo allo studio clinico e radiodiagnostico delle lesioni osteoarticolari da mallattia dei cassoni. Atti e memorie della S.O.T.I.M.I.

MeEsters, J. N. (1958): Caissonziekte. Thesis, University of Amsterdam.

Merle d'Aubignt, R. (1964): Idiopathic Necrosis of the Femoral Head in Adults. Annals of the Royal College of Surgeons, of England, 34, 143.

Ministry of Labour and National Service (1958): Work in Compressed Air Special Regulations. London: H.M.S.O.

Molfino, F. (1961): Le artropatie barotraumatiche. Minerva Medica, 52, 247.

Mosinger, M., and Jullien, G. (1961): L'expertise des ostéo-arthroses consécutives aux accidents de décompression. Annales de médecine légale, criminologie, police scientifique et toxicologie. 41, 597.

Mungo, A., and Sessa, G. (1958): Alterazioni radiologiche dello scheletro nei lavoratori dei cassoni. Folia Medica (Napoli), 41, 819.

Nicolas, M. (1949): Notions nouvelles sur la maladie de l'air comprimé et son traitement dans le travail en tube ou caisson. Médecin d'Usine, 11.

Cited by RózSAHEGYi, I. (1956): Archiv für Gewerbepathologie und Gewerbehygiene, 14, 483.

Nicolet, L., Mérer, P., and JAffres, R. (1961): De l'éxistence des manifestations neurologiques chez des travailleurs en caisson preséntant des lésions ostéo-articularies barotraumatiques. Revue du rhumatisme et des maladies ostéo-articulaires, 28, 241.

Norman, A., and Bullough, P. (1963): The Radiolucent Crescent Line-an Early Diagnostic Sign of Avascular Necrosis of the Femoral Head. Bulletin of the Hospital for Joint Diseases, 24, 99.

Paton, W. D. M., and Walder, D. N. (1954): Compressed Air Illness-an Investigation During the Construction of the Tyne Tunnel, 1948-1950. Special Report Series, Medical Research Council, London, No. 281.

Patterson, R. J., Bickel, W. H., and Dahlin, D. C. (1964): Idiopathic Avascular Necrosis of the Head of the Femur. Journal of Bone and Joint Surgery, 46-A, 267.

Phemister, D. B. (1940): Changes in Bones and Joints Resulting from Interruption of Circulation. II. Nontraumatic Lesions in Adults with Bone Infarction; Arthritis Deformans. Archives of Surgery, 41, 1455.

Phemister, D. B. (1949): Treatment of the Necrotic Head of the Femur in Adults. Journal of Bone and Joint Surgery, 31-A, 55.

Pirastu, E., and Perra, L. (1960): Contributo clinico-sperimentale allo studio dell'infarto osseo e della malattia dei cassoni. Rassegna Medica Sarda, 62, 819.

Poppel, M. H., and Robinson, W. T. (1956): The Roentgen Manifestations of Caisson Disease. American Journal of Roentgenology, 76, 74. 
Ratnoff, O. D. (1943): The Absence of Roentgenographically Demonstrable Bony Changes at the Hip Joint in Subjects Exposed to Simulated High Altitudes. U.S., A.A.F. School of Aviation Medicine, Project No. 217, Report No. 1.

Ravault, P., Mérer, P., Roche, L., and Rayneau, G. (1953): Les ostéoarthropathies des caissons dues au travail en air comprimé. Revue du rhumatisme et des maladies ostéo-articulaires, $20,587$.

RAYMOND, V. (1948): Les ostéo-arthrites pneumatiques. Lésions osseuses des tubistes et des scaphandriers. Archives des maladies professionnelles, de médecine du travail et de sécurité sociale, 9, 437.

Raymond, V. (1960): Arthroses baro-traumatiques. Archives des maladies professionnelles, de médecine du travail et de sécurité sociale, 21, 609.

Reboul, J., Delos, J., Delorme, G., Groc, J. de, Bordron, H., and Carraze, G. (1955): Radiodiagnostic des complications ostéo-articulaires de la maladie des caissons. Journal de radiologie d'électrologie et de médecine nucléaire, 37, 685.

Rendich, R. A., and Harrington, L. A. (1940): Roentgen Findings in Caisson Disease of Bone, with Case Reports. Radiology, 35, 439.

Rettig, H. (1951): Caissonnekrose am Hüftkopf. Monatsschrift für Unfallheilkunde und Versicherungsmedizin, $54,338$.

Roche, L., and RayneaU, G. (1953): Les ostéo-arthropathies chez les ouvriers travaillant en air comprimé. Archives des maladies professionnelles, de médecine du travail et de sécurité sociale, 14, 233.

Roche, L., Devic, M., Genevois, M., and MARIN, A. (1956): La tomographie osseuse dans l'ostéoarthropathie des caissons. Archives des maladies professionnelles, de médecine du travail et de sécurité sociale, 17, 597.

Ronald, J. (1953): Aseptic Necrosis of Bone in Caisson Disease. Lancet, ii, 855.

Rose, R. J. (1962): Survey of Work in Compressed Air During the Construction of the Auckland Harbour Bridge. Special Report No. 6, Medical Statistics Branch, Department of Health, Wellington, New Zealand.

RózSAHEGYI, I. (1956): Die chronische osteoarthropathie der Caissonarbeiter. Archiv für Gewerbepathologie und Gewerbehygiene, 14, 483.

RózSAHEGYI, I., and FRIED, L. (1963): Untersuchungen über die Entstehung und Dynamik der chronischen Osteoarthropathie des Caissonarbeiter. Zeitschrift für die gesamte Hygeine und ihre Grenzgebiete, 12, 915.

SARTOR, E. (1947): Skelettförändringar vid tryckluftsjuka. Nordisk Medicin, 35, 1551.

SChröder, G. (1956): Klinisch-röntgenologischer Beitrag zum Problem des Knockeninfarktes bei Caissonarbeitern. Monatsschrift für Unfallheilkunde und Versicherungsmedizin, 59, 161.

Sèze, S. De, Durieu, J., Brux, J. De, Guéguen, Y., and Welfing (1951): A propos d'un cas de " maladie des caissons." Revue du rhumatisme et des maladies ostéo-articulaires, 18, 469.

SløRDAhl, J. (1953): Aseptisk bennekrose ved dykkersyke. Tiddsskrift for den Norske Laegeforening, 73, 300.

Suntych, F., and SuntychovÁ, M. (1961): Knochenverränderungen bei der Caissonkrankheit. Radiologia diagnostica, 2, 397.

Swain, V. A. J. (1942): Caisson Disease (Compressed-air Illness) of Bone with a Report of a Case. British Journal of Surgery, 29, 365.

TARA, S. (1956): Lésions ostéoarticulaires retardées des tubistes. Archives des maladies professionnelles, de médecine du travail et de sécurité sociale, 17, 477.

TAYLOR, H. K. (1943): Aseptic Necrosis and Bone Infarcts in Caisson and Non-caisson Workers. New York State Journal of Medicine, 43, 2390.

TAYLOR, H. K. (1944): Aseptic Necrosis in Adults: Caisson Workers and Others. Radiology, 42, 550.

Thomson, J. D., and Young, A. B. (1958): Aseptic Necrosis of Bone in Caisson Disease. British Journal of Industrial Medicine, 15, 270.

Twynam, G. E. A. (1888): A Case of Caisson Disease. British Medical Journal, i, 190.

WAlKer, W. A. (1940): Aseptic Necrosis of Bone Occurring in Caisson Disease. A Case Report. Journal of Bone and Joint Surgery, 22, 1080. 